\title{
Observations from PEMS testing of combustion engines of different applications
}

\begin{abstract}
The article compares data obtained in road tests with the latest legislative proposals relating to various applications of internal combustion engines. Passenger car emission tests have been performed several times on the same test route in accordance with the RDE procedure guidelines, for which a dozen or so criteria must be met, including the distance of each of the drive sections, their in the drive time and the dynamic characteristics of the drive. The analysis was also based on a two-dimensional operating density characterization, presented in the vehicle speed-acceleration coordinates. As a result, it was possible to compare dynamic properties, operating time density and, thus, to check the validity of conducted drive tests in terms of their feasibility and emission values. An exhaust emission related comparison of three types of powertrain have been presented: gasoline, diesel and hybrid in the RDE tests. The authors proposed a new form of presenting the road exhaust emissions results in relation to the carbon dioxide emission, referred to as a standardization of the emission results. The exhaust emissions from city buses fitted with different powertrains tested on an actual bus route and in the SORT test were also compared.
\end{abstract}

Keywords: exhaust emission, passenger cars, road tests, Real Driving Emissions

\section{Introduction}

Currently, a trend towards a more global consideration of environmental threats from the automotive industry can be observed. The provisions approving the use of vehicles (type approval tests and production compliance), periodic technical inspections and legal acts related directly and indirectly to the production, use and management of used products and waste treat the issues of environmental protection in a more comprehensive manner. Over the past years, there have been various systems for vehicle exhaust emissions measurement and control in individual countries, however a widespread unification began more recently [1, $5,25,34]$.

The dynamic development of transport in the last decades is an important factor in the world economic development and at the same time a significant source of problems related to it, especially significant on the local scale, especially in large urban agglomerations. The negative effects of transport are noticeable both for the natural environment and society. The widespread development of this sector has allowed society to overcome a significant barrier to civilization development, the effects vary depending on the level of economic development, level of advancement and use of various transport sectors, geographical location (mainly climate), as well as the sensitivity of the environment.

Preventing threats from transport from occurring, and when it is not possible - limiting their environmental impact, as well as the scale and scope of negative effects is extremely important [41]. Appropriate activities should be taken at administrative levels of authority, local governments as well as in the private sector. It is necessary to introduce appropriate legal and administrative regulations, provide adequate financial resources and human potential for the development of new technologies, spatial planning, rational design and maintenance of infrastructure, as well as for educating the public and rationalizing transport tasks.
The growing number of vehicles in the world and the rising pollution levels lead to an increase in the requirements placed to reduce exhaust emissions. Additionally the current level of technology advancement and technology in the industry, including all types of transport, increases the quality level of emission measuring devices [4, 8, 9]. In order for products to meet these requirements to an appropriate extent regarding the periodically changing regulations, the industry focus had to shift towards this aspect. Exhaust emission testing bears a significant level of complexity. Current emission analyzers require specific laboratory conditions, and type approval procedures include tests on engine and chassis dynamometers. Those, however, do not reflect the actual emissions in real operating conditions. The results of latest tests conducted in real conditions indicate that for some exhaust components this emission is higher by several hundred percent in case of both gas compounds $[18,21,28]$ and particulates $[32,35,39]$. As a result, there is a visible trend towards the implementation of emissions measurement in real operating conditions for conventional [2, 23, 29] and hybrid vehicles [36. 40] as well as for two- and three-wheeled vehicles [38].

The fuel crisis of the 1970s made the world realize that the natural energy resources are limited. Nowadays, exceeding the ecological barrier is more and more often considered to be more dangerous than the depletion of fuel resources [6], especially since the issues of environmental protection in the world energy policy are not given due urgency in some countries. The increase in the world's vehicle number leads to significant amounts of carbon dioxide, but it also depend on the types of transport and their use. In line with the European Union strategy, in force since 1995, the average level of carbon dioxide emissions from vehicles has been reduced to $130 \mathrm{~g} / \mathrm{km}$ in 2015, and in 2020 this level in Europe is to be down to only $95 \mathrm{~g} / \mathrm{km}$ [13].

The main research and development direction for manufacturers of vehicle drive systems, is a system based on the cooperation of a combustion engine and electric drive, i.e. 
hybrid drive (Fig. 1). Hybrid vehicles currently have a noticeable share in the car market [3]. In the span of the next 15-20 years, hybrid drives should reach about $25 \%$ share of all new vehicles sold in the European Union. At the same time, other modern drive systems, such as the classic electric drive that draws energy from batteries and fuel cells, are expected to gain several percent of the market share.
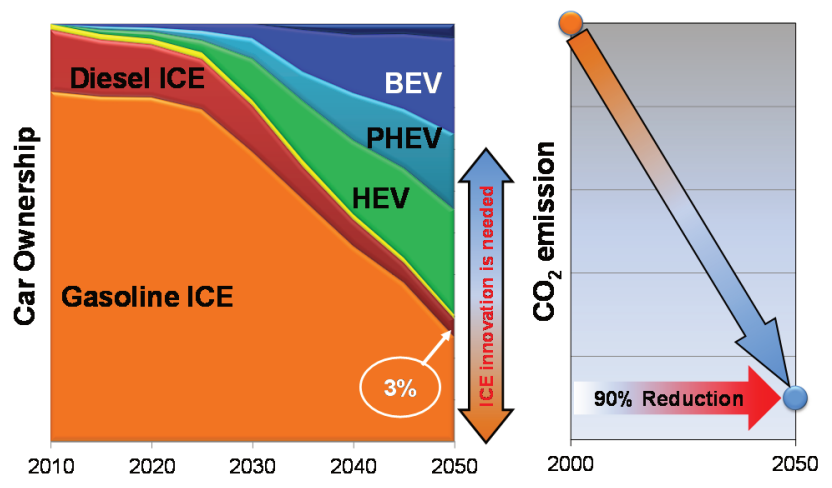

Fig. 1. Future power source trend and $\mathrm{CO}_{2}$ target [12]

The key technological factors for the development of internal combustion engines can be assessed in three aspects [19, 26, 29-32]:

- exhaust emission tests in RDE (Real Driving Emissions) traffic conditions, which results in the extension of the repeatable dynamometer tests by tests performed in various road conditions (Fig. 2),

- lowering the limit values of carbon dioxide emission will cause electrification of vehicle drives, which will force conventional combustion engines to reduce fuel consumption and increase their efficiency,

- lower exhaust emissions limits of harmful compounds result in a further reduction of $\mathrm{NO}_{\mathrm{x}}$ emissions for Diesel engines, while for SI engines with direct fuel injection a significant issue is the reduction of the number of particles.

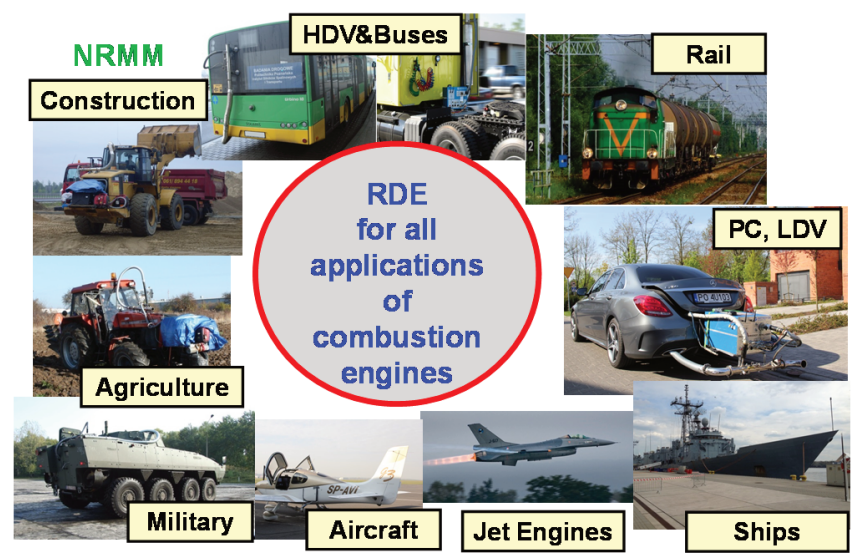

Fig. 2. Poznan University of Technology - large experience in RDE measurements [24]

\section{Validation of RDE procedure requirements}

The research route on which the tests were performed was designed to meet the European Commission require- ments as described in the regulations $[10,11] .8$ measurement cycles were made while meeting the real driving conditions requirements in urban, rural and motorway areas in and around the city of Poznan. The average distance traveled was $80 \mathrm{~km}$ (Fig. 3, Table 1).

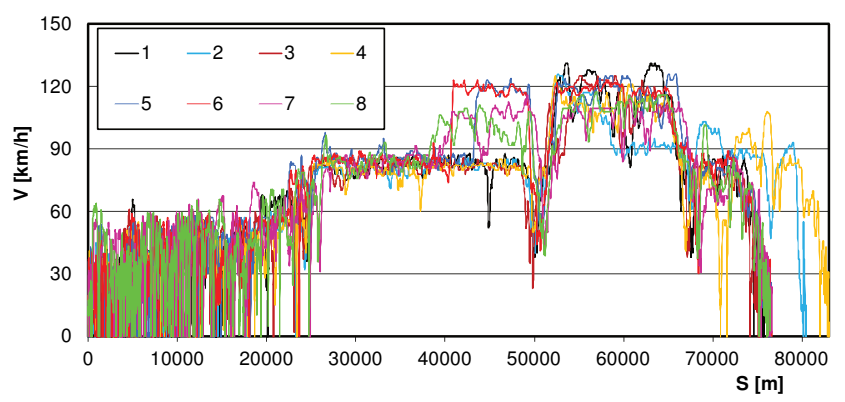

Fig. 3. All RDE tests were characterized by similar parameters and had similar speed profiles

Tab. 1. Drive cycle parameters (acceleration, constant vehicle speed, braking, stop) relative to the average value

\begin{tabular}{|l|c|c|c|c|}
\hline \multicolumn{1}{|c|}{$\begin{array}{c}\text { Test } \\
\text { number }\end{array}$} & $\mathrm{a}>\mathbf{4}$ & $\mathrm{V}=$ const & $\mathrm{a}<0$ & $\mathrm{~V}=0$ \\
\hline Test 1 & 20 & 39 & 20 & 21 \\
\hline Test 2 & 20 & 51 & 19 & 10 \\
\hline Test 3 & 22 & 41 & 20 & 17 \\
\hline Test 4 & 21 & 41 & 20 & 18 \\
\hline Test 5 & 23 & 34 & 23 & 19 \\
\hline Test 6 & 26 & 34 & 26 & 14 \\
\hline Test 7 & 33 & 21 & 30 & 16 \\
\hline Test 8 & 32 & 17 & 31 & 20 \\
\hline Average & 24.6 & 34.7 & 23.6 & 16.9 \\
\hline
\end{tabular}

Analysis of the route distance data in the urban section showed that the drive No. 2 had the largest distance covered, while the shortest was drive No. 4, however the length values of all drive cycles were within the acceptable range, i.e. they were greater than $16 \mathrm{~km}$ (Fig. 4a). Route data analysis for the rural section indicated that the longest route was travelled during drive No. 2, and the shortest for drive No. 8. The distances covered in all drive cycles were within the acceptable range, i.e. they were greater than $16 \mathrm{~km}$ (Fig. 4b). The motorway section was the longest for the drive No. 8, and the shortest for the drive No. 1. The route distances for drives No. 1 and 3 were too small. The remaining drives were within the acceptable range, i.e. their distance was longer than $16 \mathrm{~km}$, and the average was $24.66 \mathrm{~km}$ (Fig. 4c).

The urban drive section time density was the highest for the drive No. 3 , and the smallest - for the drive No. 2. The time density of the urban part of all drives (except for the drive No. 2) were all within the valid range of $29-44 \%$ (Fig. 5a). Time density of the rural section of the drive was the highest for the drive No. 1, and the lowest - for the drive No. 8. But these values were only deemed acceptable for drives No. 5-8 as being in the range of $23-43 \%$. The remaining drives did not meet this requirement and were thus deemed invalid (Fig. 5b). 
a)

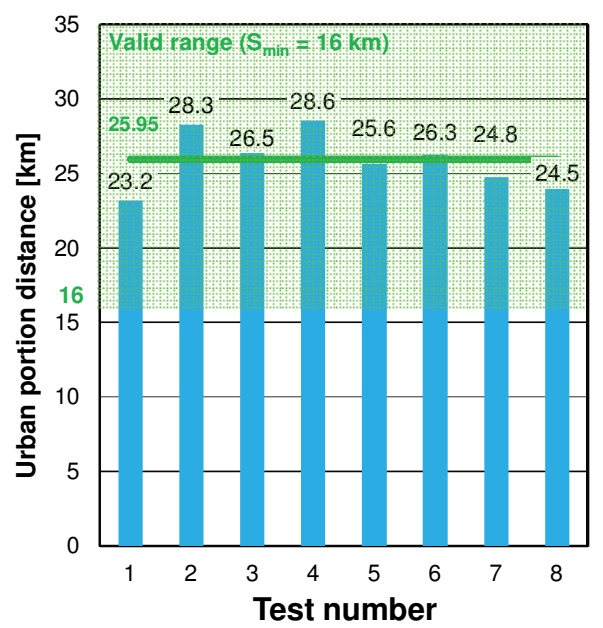

b)

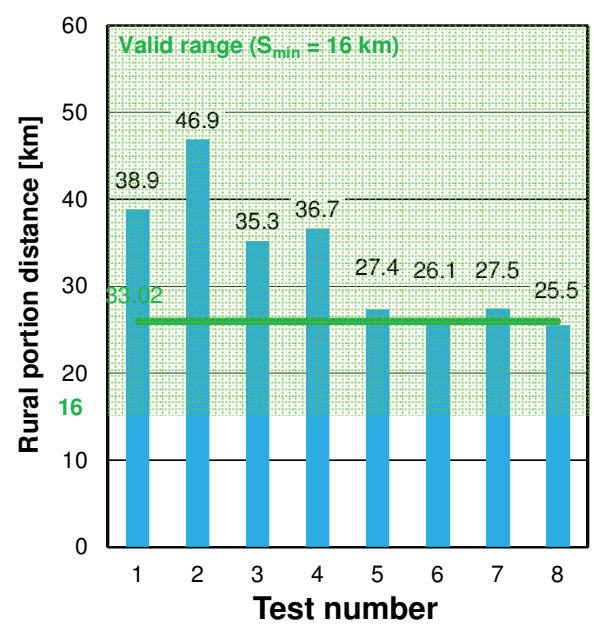

c)

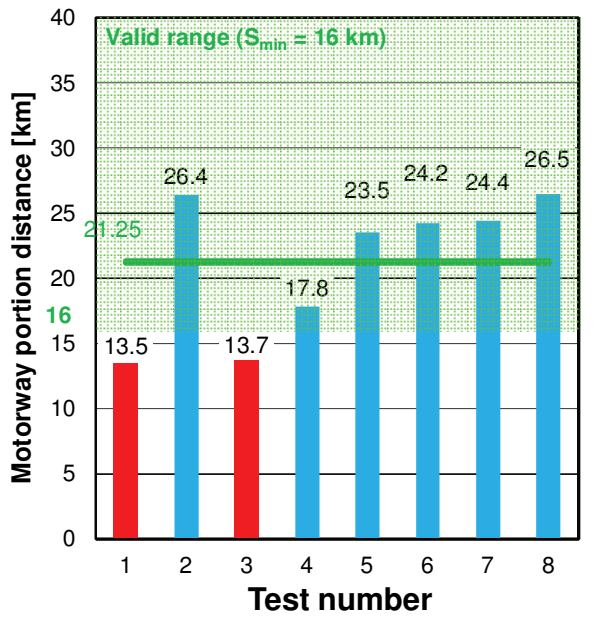

Fig. 4. Comparison of urban (a), rural (b) and motorway (c) section distances with a minimum value (required) for all drives as well as the average

The highest time density value for the motorway section drives data analysis was found for drive No. 8, and the smallest - for drive No. 1. The rural section time density values were in the valid range of $23-43 \%$ for all drives except the drives No. 1, 3 and 4 (Fig. 5c). a)

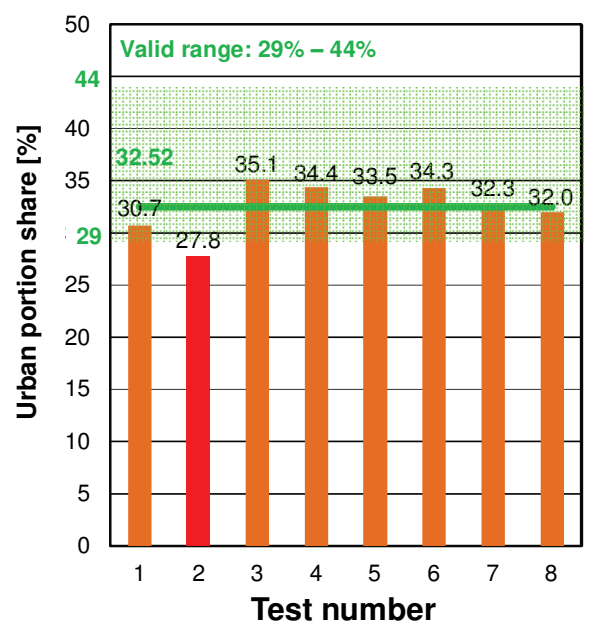

b)

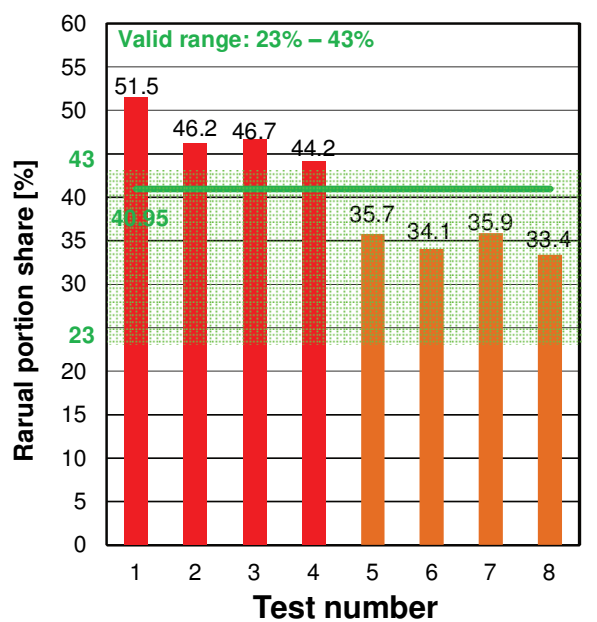

c)

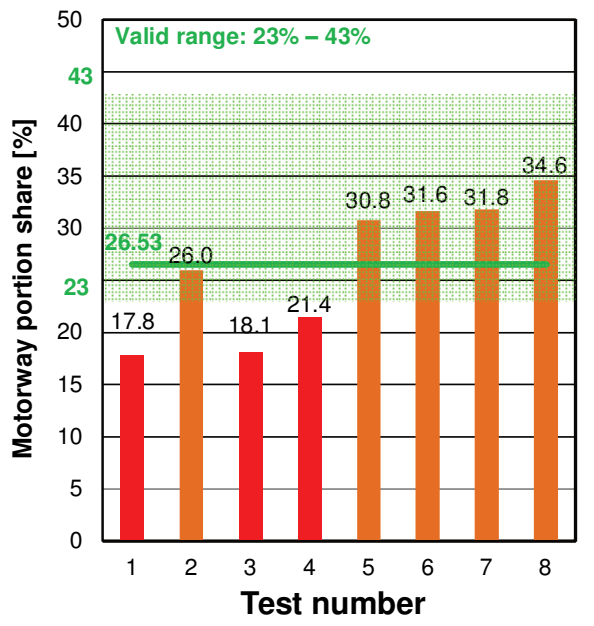

Fig. 5. Comparison of the urban (a), rural (b) and motorway (c) sections share in the drive cycles with the limit values (required) indicated for all drive cycles as well as the average value

The average speed data analysis in the urban section showed that the highest speed was found for drive No. 2, and the smallest speed for drive No. 1. The average speed values of all drives are within the required range, i.e. from $15 \mathrm{~km} / \mathrm{h}$ to $40 \mathrm{~km} / \mathrm{h}$ (Fig. 6a). The drive cycle duration was the longest for the drive No. 4 , and the shortest for the drive 
No. 6. All drives were within the required time range, i.e. from 90 to 120 minutes (Fig. 6b).

a)

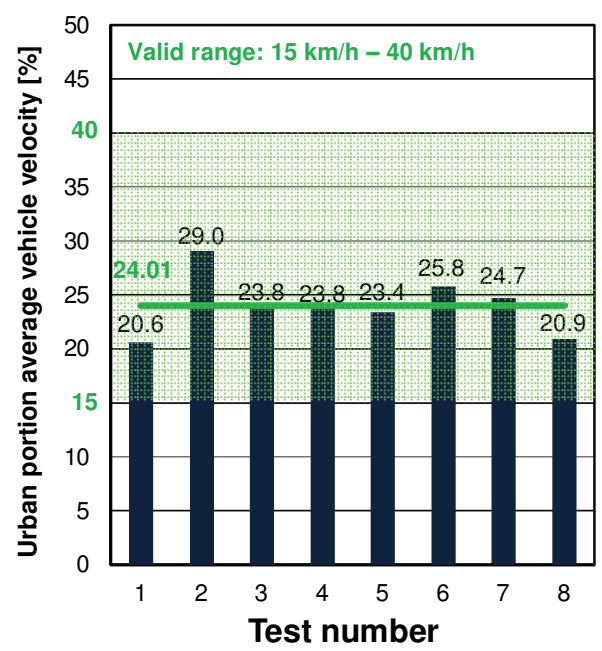

b)

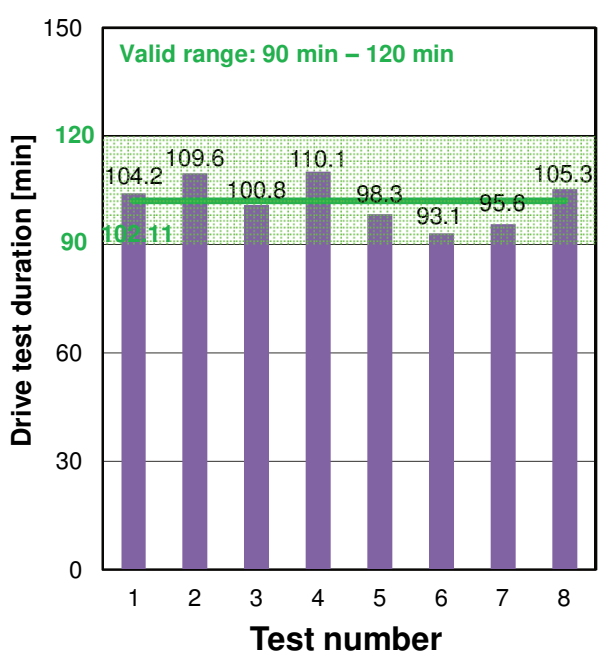

c)

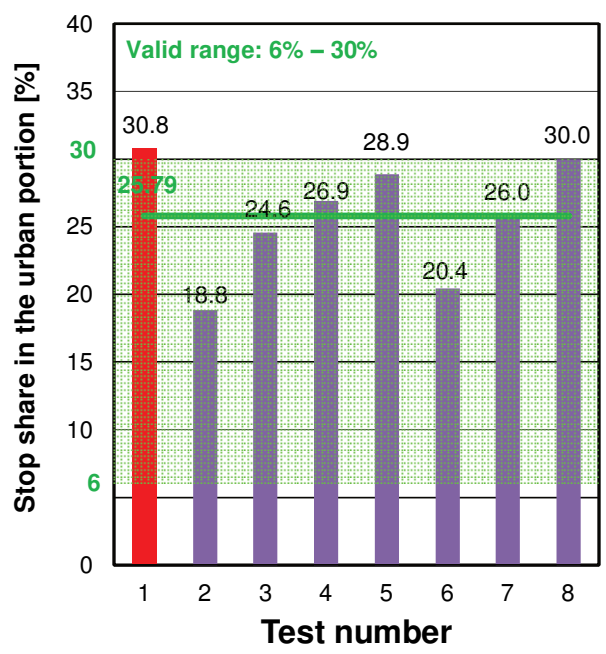

Fig. 6. Comparison between the average urban test section drive speed (a), the total test drive duration (b) and the vehicle stop participation in the urban section with the indication of limit values (required) for all the drives as well as the average value
The data analysis on the standstill time density in the urban section indicated that the drive No. 1 had the highest share value, and drive No. 2 the smallest. All drives reached the total drive cycle share of vehicle standstill that was within the acceptable range, i.e. 6-30\%. Drive No. 1 was the only exception, as it did not meet this requirement (Fig. $6 c)$.

Figure 7 is a two-dimensional representation of the vehicle time density characteristics for valid drives (drives 58), which can be described as follows: the largest share of vehicle operation time in the tested traffic conditions is vehicle standstill and moving at a constant speed $(\mathrm{V}=$ $=16-36 \mathrm{~m} / \mathrm{s}$ for $\mathrm{a}=0 \mathrm{~m} / \mathrm{s}^{2}$ ).

a)

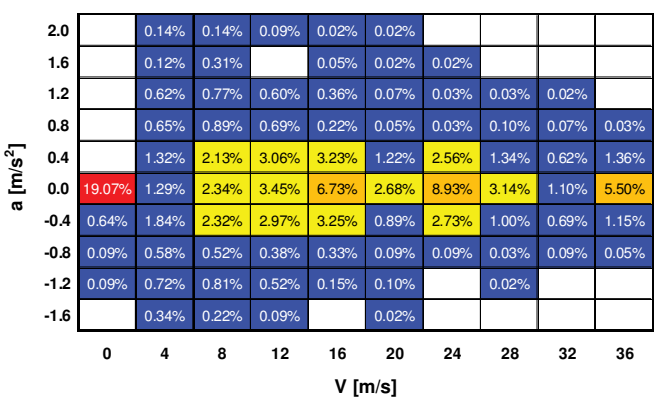

b)

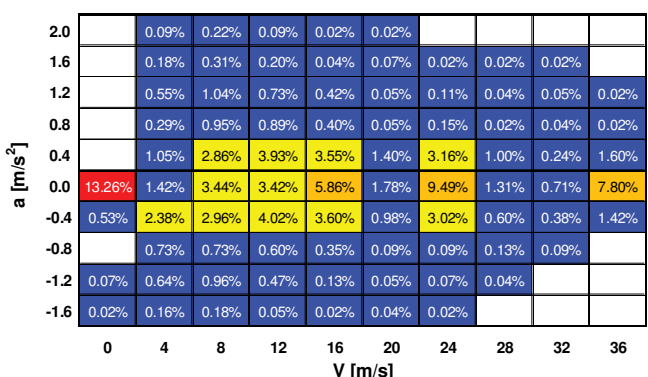

c)

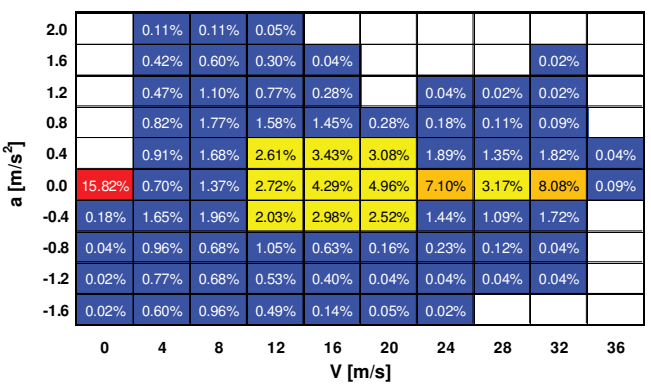

d)

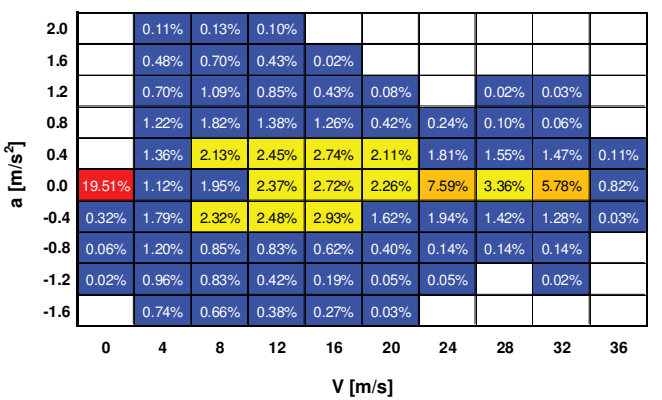

Fig. 7. Vehicle's operating time density in individual speed and acceleration ranges: a) for drive No. 5 , b) for drive No. 6 , c) for drive No. 7 d) for drive No. 8 
For all the drive cycles the largest operating time density for the vehicle was observed for the idle mode and the average speed value range $\left(\mathrm{V}=24 \mathrm{~m} / \mathrm{s}\right.$ for $\mathrm{a}=0 \mathrm{~m} / \mathrm{s}^{2}$ except for drive No. 7). This is the result of a constant driving speed in the rural area. For the valid drives, variable acceleration values in the range $\left(-0.4 \mathrm{~m} / \mathrm{s}^{2}, 0.4 \mathrm{~m} / \mathrm{s}^{2}\right)$ are visible in the vehicle operating characteristic.

The drives labelled 5-8 were all valid and for these drives average values were determined, which were marked as "reference" (Fig. 8).

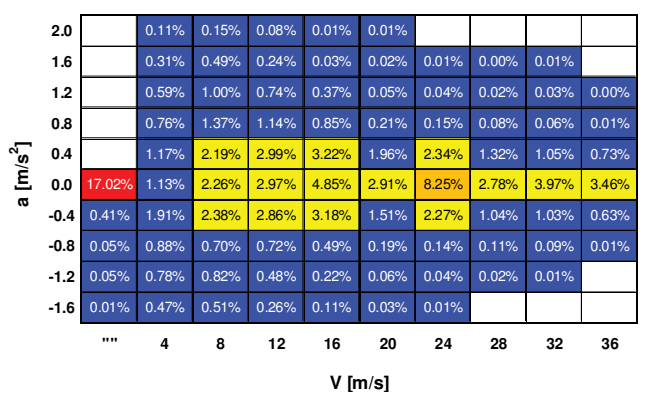

Fig. 8. Vehicle's operating time density in individual speed and acceleration intervals for the "reference" drives

The road emission values were determined using previous research with simultaneous measurement of exhaust emissions. Due to the fact that the tests were performed for a vehicle with a Euro $6 \mathrm{~b}$ emission class gasoline engine (without a particle filter - GPF), the emission of carbon dioxide, carbon monoxide, hydrocarbons, nitrogen oxides and the number of particles was measured (Fig. 9). The obtained results were presented for all eight drives with the indication that the first four drives did not meet the formal requirements of the test drive cycle (marked in red), however, this fact did not invalidate the road emission results that can be obtained from them. Invalid drives are marked in red, while the parameter value range for a drive to be valid (as for drives marked 5-8) is marked in green.

The emission limits shown in Fig. 9, marked as Euro 6d-Temp, refer to future emission standard (coming into force on 1.09.2017), where the emission limits are provided as:

- for nitrogen oxides at 2.1,

- for particle number at 1.5

relative to the emission value limits of Euro $6 \mathrm{~b}$.

Analysis of individual pollutant emission values indicates a similar nature of the obtained data, which is discussed below.

The maximum road emissions value of carbon monoxide (Fig. 9) for valid drives was $356 \mathrm{mg} / \mathrm{km}$ (drive 8), and the minimum value is $264 \mathrm{mg} / \mathrm{km}$ (drive 6). Drive No. 6 was characterized by a low RPA (Relative Positive Acceleration) value from among the valid drives. Obtained road emission values did not exceed the limit values, specified in the Euro $6 \mathrm{~b}$ standard for passenger vehicles equipped with gasoline engines $(1000 \mathrm{mg} / \mathrm{km})$ for all performed drive tests.

The emission of nitrogen oxides (Fig. 10) changed (for drives compliant with the RDE requirements) from 39.7 $\mathrm{mg} / \mathrm{km}$ (drive 5) to $44.9 \mathrm{mg} / \mathrm{km}$ (drive 8 ). Road emissions values in all drives did not exceed the permissible limit, i.e. $60 \mathrm{mg} / \mathrm{km}$.

The character of the particle number road emission was similar to the previous results (Fig. 11): the highest value was obtained for drive No. $8\left(4.3 \cdot 10^{12} 1 / \mathrm{km}\right)$, while drive No. 6 had the lowest value $\left(2.5 \cdot 10^{12} 1 / \mathrm{km}\right)$.

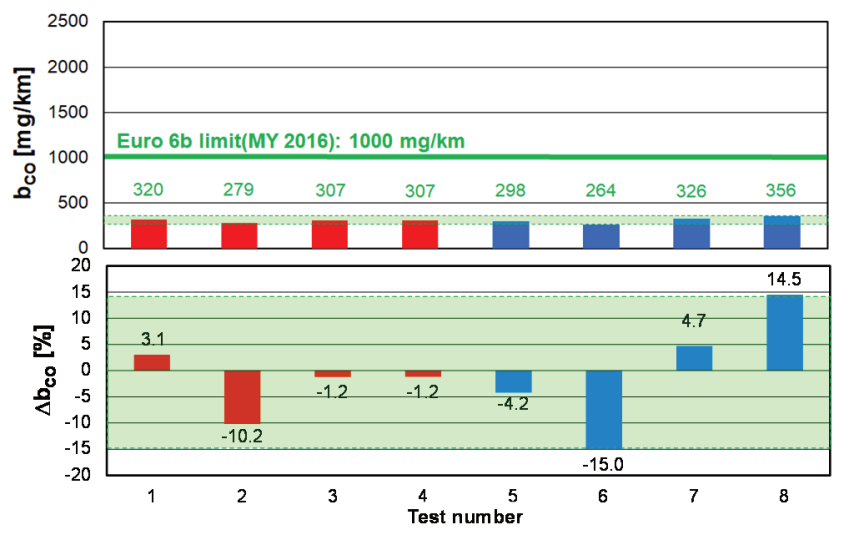

Fig. 9. Carbon monoxide road emissions and relative error for all completed drives; invalidated drives are marked in red, while the parameter value range of valid drives (5-8) is marked in green

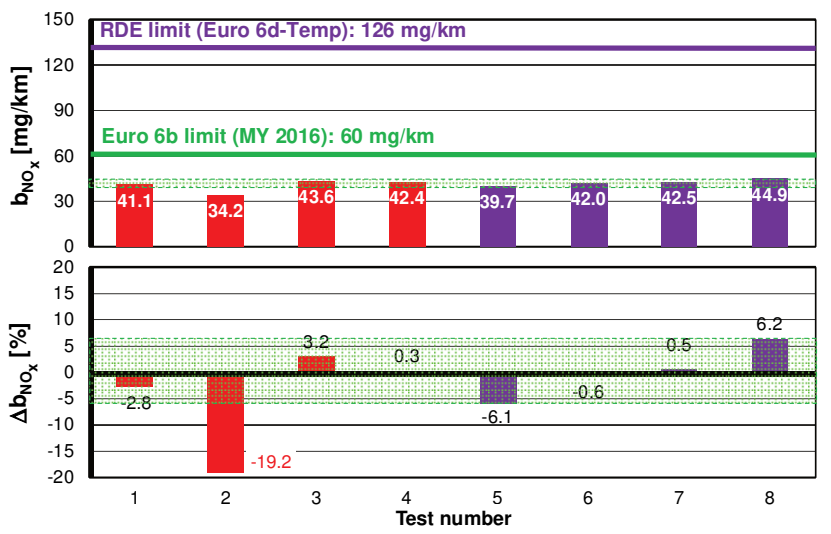

Fig. 10. Road emission of nitrogen oxides and relative error for all drives

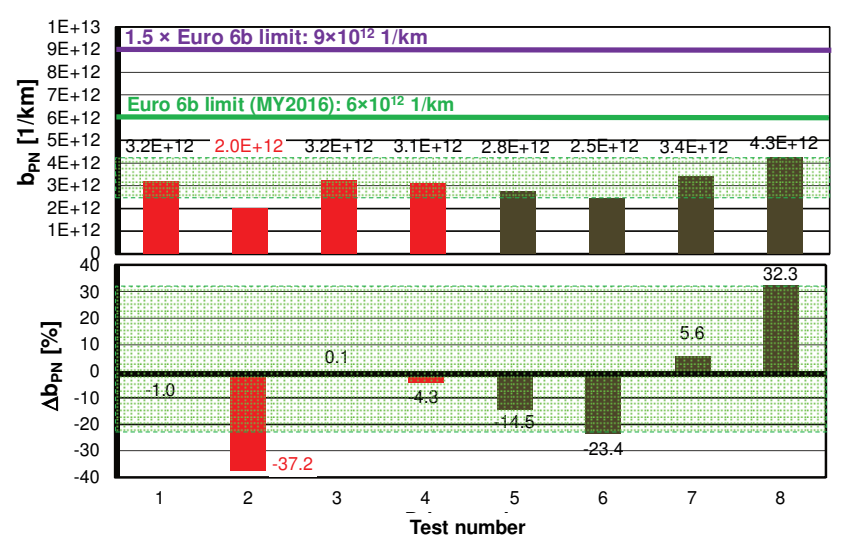

Fig. 11. Particle emission number and relative error for all drives

In order to compare the value ranges in individual road exhaust emissions, a relative error was determined for each component of the road emission in each drive, as described by the formula: 


$$
\Delta b_{j}=\frac{b_{j, a v g(5-8)}-b_{j}}{b_{j}}
$$

where: $b_{\mathrm{j}, \text { avg(5-8) }}$ - average road exhaust emissions value from drives $5-8, b_{\mathrm{j}}-$ individual pollutant road emission value.

Analysis of individual relative errors values allows the following relationships to be found:

- the relative error of carbon monoxide road emissions values between individual drives does not exceed $15 \%$; all drives were within this range (including the drives that failed to meet the RDE requirements). In this case, the highest relative error values (i.e. $14.5 \%$ and $-15 \%$ ) were obtained for the valid RDE tests. The relative error of carbon monoxide road emissions for invalid tests was lower than in the case of valid ones, i.e. carbon dioxide emission values obtained from the tests not meeting the $\mathrm{RDE}$ requirements were mostly similar to each other in contrast to the values obtained in the tests that were valid for the RDE procedures;

- the relative error value of nitrogen oxides road emissions between individual drives did not exceed about $6 \%$; all drives were in this range - except for drive No. 2 (not meeting RDE requirements), whose result was reported to be lower by about $20 \%$ from the average value of the valid drives. At the same time, there is no unambiguous trend in the values of relative error for invalid drives;

- the nature of the relative particle number error confirms the previous results, that the relative error between individual valid drives is the largest and exceeds $30 \%$; all drives were in this range - except for drive No. 2.

The analysis of individual requirements specified in Regulations 2016/427 [11] and 2016/646 [12] confirmed the validity of the RDE test procedure for four out of eight performed drive tests. Invalid drives were characterized by either too short drive distance, too small share of driving in particular test sections, too long time spent idle in the urban section and too low driving dynamics in the rural part.

The analysis of the test results does not allow to unambiguously determine the errors and uncertainties of the obtained emission results with the assumed number of road test errors made.

However, it should be noted that the highest values of road exhaust emissions were obtained for drives in which the urban section share was small but with a large share of the motorway section. This shows a significant impact of RDE test sections on the road emission results, where a high engine load is used, and the exhaust emission intensity is greatest (as well as the of exhaust aftertreatment systems efficiency not being at maximum).

The conducted research lead to determining the scatter of the obtained exhaust emission results for RDE tests performed in accordance with the European Union procedures. The results scatter values (for passenger vehicles with direct fuel injection gasoline engines, meeting the Euro $6 \mathrm{~b}$ standard) were as follows:

- for carbon monoxide road emissions results the scatter was $\pm 15 \%$,
- for nitrogen oxides road emissions results the scatter was $\pm 6 \%$,

- for particle number road emissions results the scatter was $\pm 32 \%$.

However, the issue of a greater impact of the RDE test section or driving dynamics (defined by indicators of relative positive acceleration or the product of velocity and acceleration) on the exhaust emission values was not resolved in this research. Describing and testing these relations will be the subject of further research using passenger cars powered by various fuels and hybrid vehicles.

\section{Hybrid, Diesel and Gasoline vehicles in the RDE tests}

Three vehicles were used for the exhaust emission tests in real traffic conditions. The same vehicle models of the same manufacturer were tested, but they had different drive system solutions. The first car was a hybrid vehicle, equipped with a spark-ignition engine with an indirect multipoint gasoline injection and a displacement of $1.8 \mathrm{dm}^{3}$, working in parallel with an electric motor. The second of the tested vehicles was equipped with a compressionignition engine with common rail direct injection with a turbocharger, with a displacement volume of $1.4 \mathrm{dm}^{3}$. The last tested vehicle had an MPI gasoline engine with a displacement of $1.6 \mathrm{dm}^{3}$.

The research goal was to determine the average road exhaust emission values of all measured components for each of the tested vehicles in urban, rural and motorway driving conditions, with the use of the developed Excel spreadsheet, that was used to convert the raw data according to the EMROAD method, as proposed by the European Commission.

The traffic conditions for each of the tested vehicles were very similar (Fig. 12). The similarity results mainly from the guidelines on the conditions and dynamics of the test drives, as listed in the regulations of the European Commission [8-11]. The tested vehicles passed almost the same distances in individual driving sections. Each vehicle covered a distance of about $27 \mathrm{~km}$ in urban driving section. Distance travelled by vehicles in rural driving section was shorter than in the urban section and amounted to approx. $25 \mathrm{~km}$. The distance covered by cars while driving on the motorway was the shortest and ranged from 22 to approx. $23 \mathrm{~km}$. For urban driving, Driving at speeds below $60 \mathrm{~km} / \mathrm{h}$ was considered a part of the urban drive section, for the rural drive section all the drive time moving at speeds between 60 and $90 \mathrm{~km} / \mathrm{h}$ was used, and for the motorway section it was driving at speeds above $90 \mathrm{~km} / \mathrm{h}$. The vehicle drive speed characteristics do not differ much, because the test drives were performed on the same route and because the drives needed to meet the requirements for the distance traveled within each drive section (minimum $16 \mathrm{~km}$ for each of the three sections). The average speed of urban driving (marked in green) was about $50 \mathrm{~km} / \mathrm{h}$ for each of the tested vehicles. The average speed of driving in the rural section (marked in blue) was approx. $80 \mathrm{~km} / \mathrm{h}$ for all vehicles. The average speed of all tested vehicles in motorway driving was about $110 \mathrm{~km} / \mathrm{h}$. None of the vehicles moved at speeds exceeding $120 \mathrm{~km} / \mathrm{h}$ during the RDE test. 
The hybrid vehicle has met the requirements for dynamic drive conditions. Both the values of relative positive acceleration (RPA) and the $95^{\text {th }}$ centile of the product of speed and acceleration did not exceed the minimum and maximum limit for individual driving categories respectively (Fig. 13). The minimum required number of one hundred and fifty sets of data with acceleration values $a_{i}>0.1 \mathrm{~m} / \mathrm{s}^{2}$

Hybrid (Gasoline)
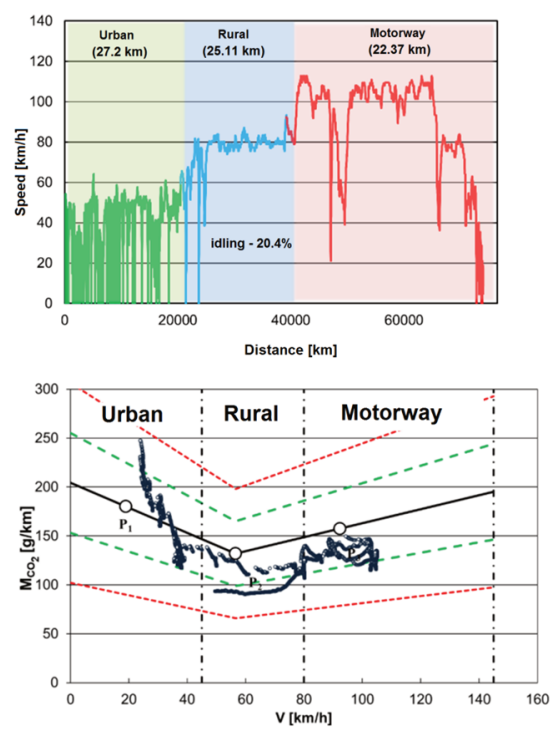

for each drive section was also met. The value of RPA was $0.19 \mathrm{~m} / \mathrm{s}^{2}$ for urban driving, $0.056 \mathrm{~m} / \mathrm{s}^{2}$ for rural driving, and $0.044 \mathrm{~m} / \mathrm{s}^{2}$ for motorway driving. The $95^{\text {th }}$ centile value of the speed and acceleration product of was $10.2 \mathrm{~m}^{2} / \mathrm{s}^{3}$ for urban driving, $15.1 \mathrm{~m}^{2} / \mathrm{s}^{3}$ for rural driving and $16.5 \mathrm{~m}^{2} / \mathrm{s}^{3}$ for motorway driving.

Fig. 12. Comparison of the traffic conditions for each of the tested vehicles

Hybrid
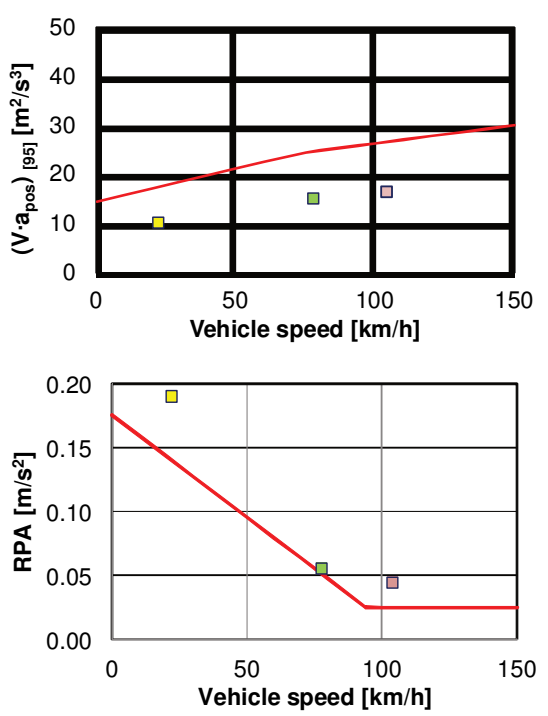

Diesel
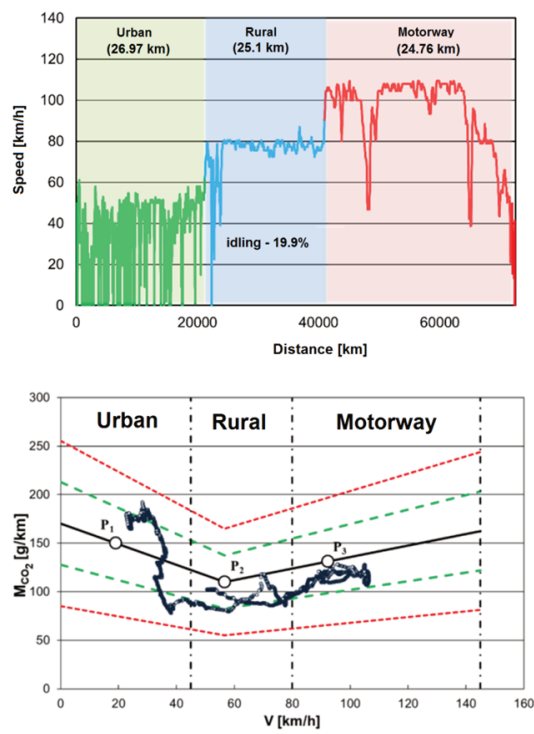

Gasoline
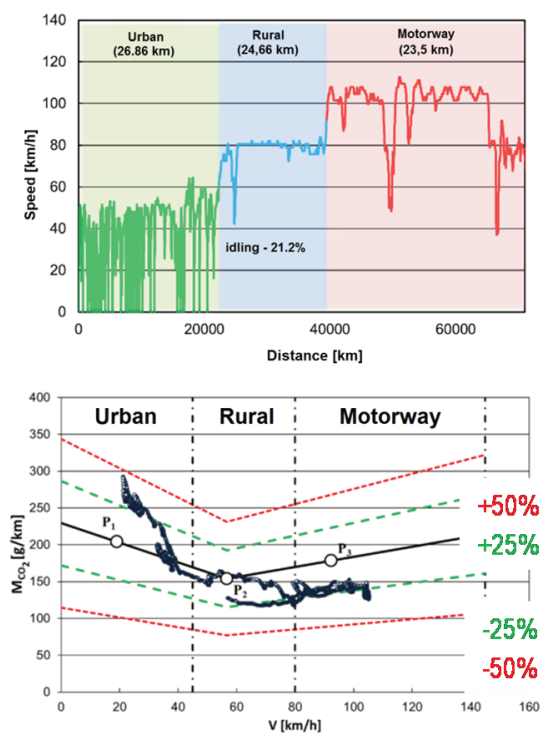

Diesel
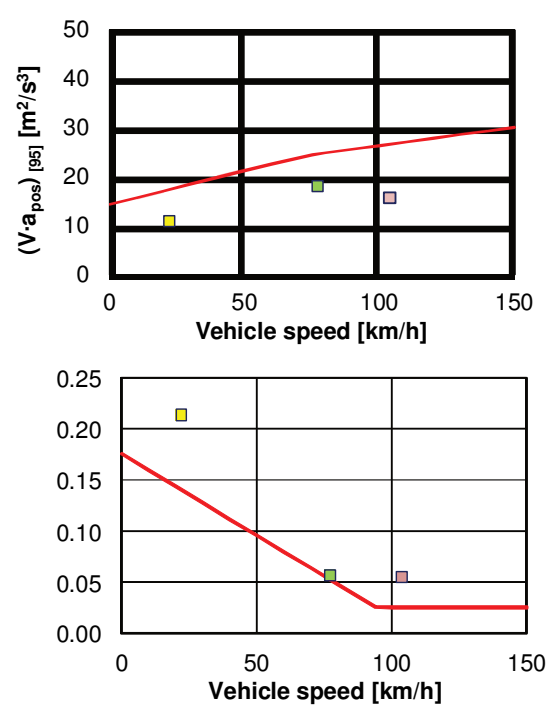

Gasoline
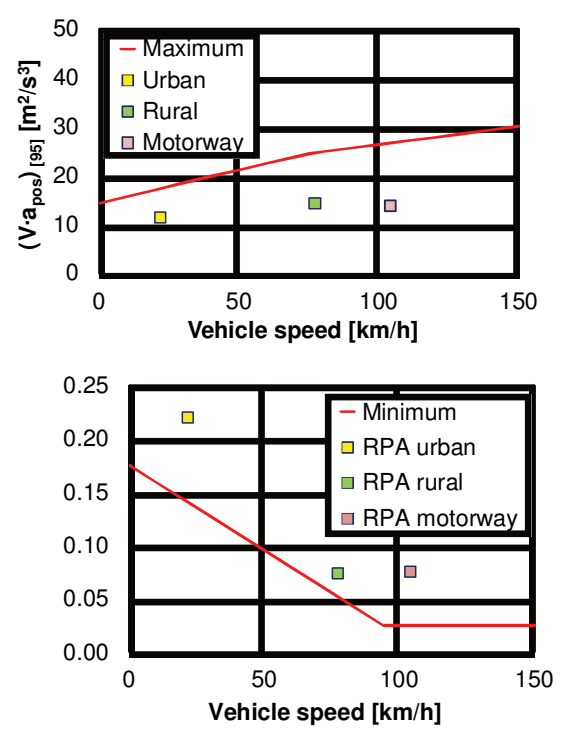

Fig. 13. Comparison of the drive dynamics conditions for each of the tested vehicles

The diesel vehicle test drive results met the requirements for dynamic conditions for the relative positive acceleration (RPA) and the 95th percentile of the velocity and acceleration product for each drive section. For urban driving the RPA value was $0.21 \mathrm{~m} / \mathrm{s}^{2}$, for rural driving it was $0.06 \mathrm{~m} / \mathrm{s}^{2}$ and for motorway driving it equaled $0.05 \mathrm{~m} / \mathrm{s}^{2}$. The value of the 95th centile $\left(\mathrm{v} \cdot \mathrm{a}_{\mathrm{pos}}\right)$ reached $11.0 \mathrm{~m}^{2} / \mathrm{s}^{3}$ for urban driving, $18.1 \mathrm{~m}^{2} / \mathrm{s}^{3}$ for rural driving and 15.78 $\mathrm{m}^{2} / \mathrm{s}^{3}$ for motorway driving.
The drive made with the vehicle with an SI engine met the drive dynamics requirements. Both the values of the relative positive acceleration (RPA) and the values of the 95th centile of the product of velocity and acceleration for each drive section were within the calculated limit values. In addition, the number of data sets with acceleration values $\mathrm{a}_{\mathrm{i}}>0.1 \mathrm{~m} / \mathrm{s}^{2}$ exceeded 150 for each the urban, rural and motorway drive sections. The value of RPA for urban driving was $0.22 \mathrm{~m} / \mathrm{s}^{2}$ for rural driving it was $0.08 \mathrm{~m} / \mathrm{s}^{2}$, and 
$0.07 \mathrm{~m} / \mathrm{s}^{2}$ for motorway driving. The values of the 95 th centile of the velocity and acceleration product $\left(\mathrm{v} \cdot \mathrm{a}_{\mathrm{pos}}\right)$ for urban, rural and motorway sections were respectively 11.4 $\mathrm{m}^{2} / \mathrm{s}^{3}, 14.3 \mathrm{~m}^{2} / \mathrm{s}^{3}$ and $13.8 \mathrm{~m}^{2} / \mathrm{s}^{3}$.

The average $\mathrm{CO}$ road emission from the hybrid vehicle for the RDE test has been shown (Fig. 14). The largest average $\mathrm{CO}$ emission was recorded for urban driving and it reached approximately $0.28 \mathrm{~g} / \mathrm{km}$. Very similar values were obtained for $\mathrm{CO}$ emissions for rural and motorway sections. With the EMROAD method, they are equal to $0.098 \mathrm{~g} / \mathrm{km}$ and $0.087 \mathrm{~g} / \mathrm{km}$ respectively, and for the method using all data: $0.08 \mathrm{~g} / \mathrm{km}$ and $0.07 \mathrm{~g} / \mathrm{km}$. The average carbon monoxide emission in the whole RDE test was $0.15 \mathrm{~g} / \mathrm{km}$. The differences in the emissions obtained by the two methods are small - in urban drive sections it is only $0.003 \mathrm{~g} / \mathrm{km}$. The largest difference is in the case of $\mathrm{CO}$ emissions is for rural driving $-0.018 \mathrm{~g} / \mathrm{km}$. The $\mathrm{CO}$ road emission, calculated using the EMROAD method, is higher for all drive sections and for the entire drive cycle.

The average road emission of carbon monoxide from a vehicle with a CI engine was the largest when driving in the urban section. The emission obtained using the EMROAD method is $0.030 \mathrm{~g} / \mathrm{km}$ and is $0.005 \mathrm{~g} / \mathrm{km}$ lower than the value obtained by the all data method. A similar noticeable difference appears in the case of rural driving emissions, except that in this case the emission determined by the EMROAD method is higher by $0.004 \mathrm{~g} / \mathrm{km}$ than the second method and equals $0.013 \mathrm{~g} / \mathrm{km}$. The average $\mathrm{CO}$ road emission in motorway driving was the smallest and for both methods it amounted to 0.011 and $0.010 \mathrm{~g} / \mathrm{km}$. While in the whole $\mathrm{RDE}$ test, the average $\mathrm{CO}$ emission reached 0.018 and $0.019 \mathrm{~g} / \mathrm{km}$ for the two methods.

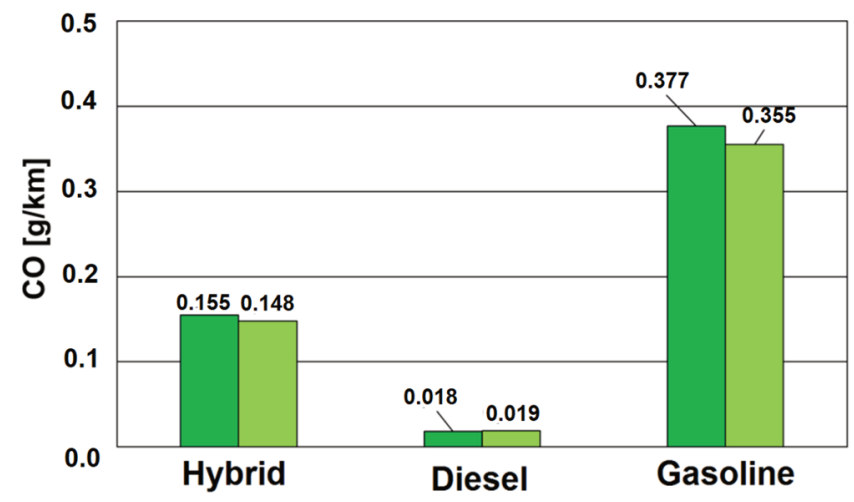

Fig. 14. CO road emission for each of the vehicles in the whole RDE test (EMROAD and all data)

The carbon monoxide road emission for the gasoline powered vehicle determined in individual drive sections varies significantly depending on the method used. In the case of urban driving, the emission determined by the moving averaging window method was $0.32 \mathrm{~g} / \mathrm{km}$ while for the classical method it was $0.47 \mathrm{~g} / \mathrm{km}$, which means that the emission determined by the classical method is more than $30 \%$ greater. The emission for the rural drive section does not differ so much between the methods, it is similar and reaches approx. $0.4 \mathrm{~g} / \mathrm{km}$. For motorway driving, the difference in road emission values obtained by the two methods is the greatest. The exhaust emission value obtained by the EMROAD method is $0.45 \mathrm{~g} / \mathrm{km}$ and is three times greater than the exhaust emission determined by the classical method. Despite very large differences in CO emission indications in individual sections, the average road emission of carbon monoxide in the whole RDE test is almost identical for the EMROAD method and the classical method, and reaching 0.36 and $0.38 \mathrm{~g} / \mathrm{km}$ respectively.

The determined average $\mathrm{CO}$ road emission is presented in the form of $\mathrm{CF}$ factors and referred to the permitted $\mathrm{CF}$ value (Fig. 15). The current regulations do not specify the absolute value of the $\mathrm{CF}_{\mathrm{CO}}$ emission index, but it should appear in future amendments to the regulations. Temporarily, the EC Regulation only recommends the registration of emission data, but as part of the analysis of the test results, a $\mathrm{CO}$ emission index limit of 2.1 has been established.

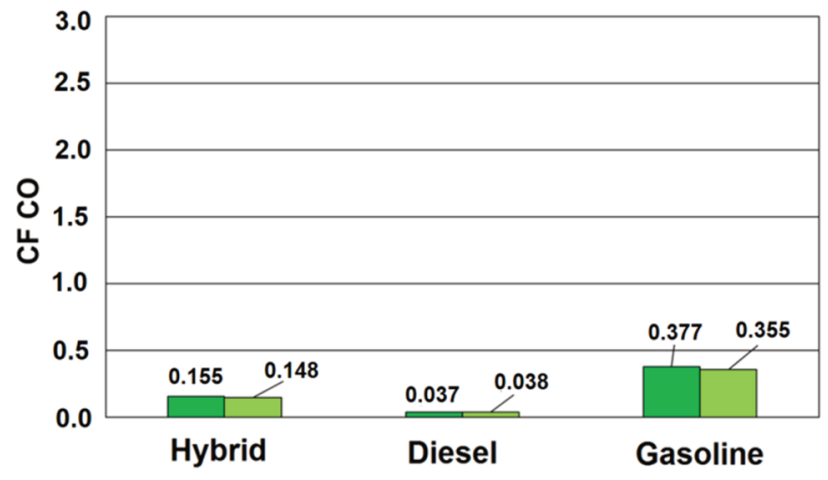

Fig. 15. Values of carbon monoxide emission factors for each of the vehicles in the whole RDE test (EMROAD and all data)

The hybrid vehicle emitted the most nitrogen oxides in the motorway drive section - approx. $0.024 \mathrm{~g} / \mathrm{km}$. Differences in relation to emissions in other categories were small. The average $\mathrm{NO}_{\mathrm{x}}$ road emission in the rural section was $0.02 \mathrm{~g} / \mathrm{km}$ for the EMROAD method and $0.022 \mathrm{~g} / \mathrm{km}$ for the method using all data. The smallest average road emission was recorded for urban driving and it was 0.0185 $\mathrm{g} / \mathrm{km}$ for the EMROAD method and $0.02 \mathrm{~g} / \mathrm{km}$ for the method using all measurement data. Interestingly, the emission determined with the use of all measurement data is greater than that determined by the moving averaging windows method, which is different from previous measured exhaust components. The average road emission of $\mathrm{NO}_{\mathrm{x}}$ in the entire RDE test is equal to about $0.22 \mathrm{~g} / \mathrm{km}$ (Fig. 16).

The average road emission of nitrogen oxides from the vehicle with a CI engine was the greatest for urban driving and equalled $0.90 \mathrm{~g} / \mathrm{km}$ with the EMROAD method and $0.82 \mathrm{~g} / \mathrm{km}$ with the all data method. The smallest emission value was recorded for rural driving and reached 0.36 and $0.32 \mathrm{~g} / \mathrm{km}$ for the two methods. In motorway driving, differences in exhaust emissions between the two methods were small and it could be said that the average emission was $0.5 \mathrm{~g} / \mathrm{km}$. In the whole RDE test, the average $\mathrm{NO}_{\mathrm{x}}$ emission was $0.588 \mathrm{~g} / \mathrm{km}$ for the moving averaging windows method and $0.56 \mathrm{~g} / \mathrm{km}$ for the method using all the measurement data. 
The results of average $\mathrm{NO}_{\mathrm{x}}$ emissions for a SI vehicle obtained by the two different methods for individual drive sections as well as the entire RDE test do not differ so much in the case of $\mathrm{CO}$ emissions. The highest average road $\mathrm{NO}_{\mathrm{x}}$ emission was recorded for urban driving, with values of 0.017 and $0.020 \mathrm{~g} / \mathrm{km}$ for the moving averaging windows method and the method using all measurement data respectively. The emission of nitrogen oxides in the urban drive section was the smallest among all the sections and reached $0.011 \mathrm{~g} / \mathrm{km}$ for the EMROAD method and $0.009 \mathrm{~g} / \mathrm{km}$ for the other method. For motorway drive section the emission results for both methods were almost the same at approx. $0.012 \mathrm{~g} / \mathrm{km}$. In the whole RDE test, the average $\mathrm{NO}_{\mathrm{x}}$ emission ranged from 0.013 to 0.014 $\mathrm{g} / \mathrm{km}$.

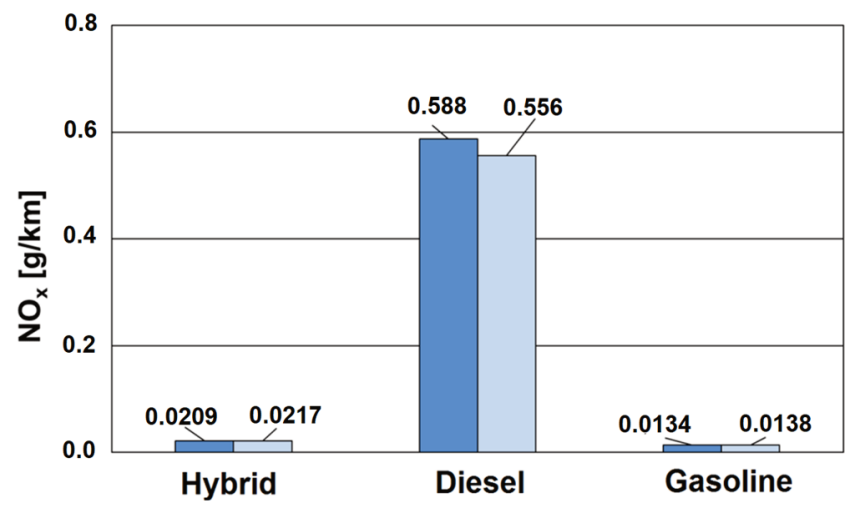

Fig. 16. Road $\mathrm{NO}_{\mathrm{x}}$ emission for each of the vehicles in the whole RDE test (EMROAD and all data)

The Euro 6 standard specifies that the $\mathrm{NO}_{\mathrm{x}}$ road emission from the tested vehicle must not exceed $0.06 \mathrm{~g} / \mathrm{km}$. The EC Regulation states that for RDE road tests the $\mathrm{NO}_{\mathrm{x}}$ emission is not to exceed the $\mathrm{CF}_{\mathrm{NOx}}$ factor equal to 2.1, which means that emissions in real driving conditions must not exceed $0.126 \mathrm{~g} / \mathrm{km}$ (Fig. 17). The $\mathrm{CF}_{\mathrm{NOx}}$ emission factors for individual drive sections are very small and range from 0.31 for urban driving to 0.40 for motorway driving. The $\mathrm{CF}_{\text {NOx }}$ factor for the whole test drive is approx. 0.35 , which means that the Euro 6 limit has not been exceeded.

The nitrogen oxide emission conformity factor for the CI vehicle clearly exceeded the legal limit value in both urban and motorway driving. For urban driving, the tested vehicle exceeded the emission limit by up to five times. And for motorway driving, the value of the $\mathrm{CF}_{\mathrm{NOx}}$ factor ranged depending on the analysis method from 2.74 to 2.83 . The smallest values of this factor were achieved when driving in rural areas and did not exceed the maximum permitted value of 2.1 , but they are still greater than 1 , which means that the emission limit itself was exceeded. The average value of the $\mathrm{NO}_{\mathrm{x}}$ emission conformity factor in the whole RDE test exceeded 3, therefore, the vehicle emits more than three times more nitrogen oxides in real driving conditions than allowed in the type approval tests on the chassis dynamometer.

The $\mathrm{NO}_{\mathrm{x}}$ emission factors obtained for an SI vehicle did not exceed the limit value of 2.1 in any drive section nor in the whole test. What is more the $\mathrm{CF}_{\mathrm{NOx}}$ factor did not ex- ceed 1, which means that in real driving conditions the vehicle did not exceed the legal emission limit value.

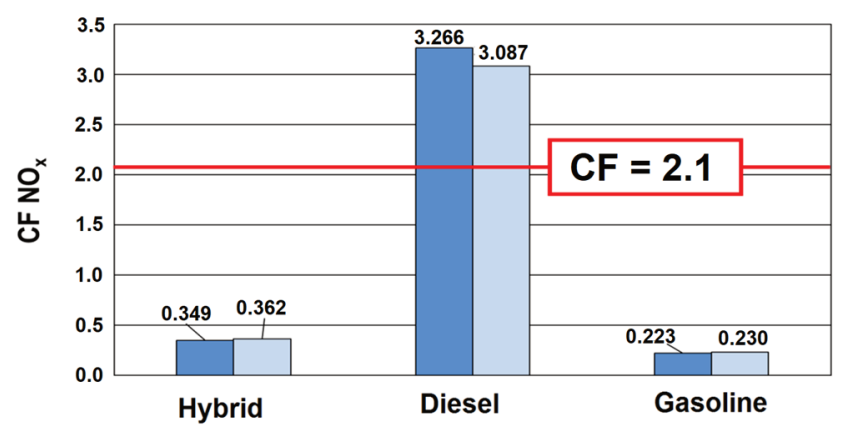

Fig. 17. Values of nitrogen oxide $\mathrm{CF}$ emission conformity factors for each of the vehicles in the whole RDE test (EMROAD and all data)

The particle number emissions from the tested hybrid vehicle vary greatly depending on the vehicle category considered (Fig. 18). In the case of particle emissions, differences in the results between the two measurement data analysis methods are noticeable. The highest emission values were recorded for the vehicle moving in urban areas. In this case, the emission determined based on all data was $1.7 \cdot 10^{12} 1 / \mathrm{km}$, while the emission obtained with the EMROAD method was lower and reached the value of $1.4 \cdot 10^{12} 1 / \mathrm{km}$. As part of the rural drive section, the emission determined using the moving averaging window method was higher at $5.2 \cdot 10^{11} 1 / \mathrm{km}$, while the emission obtained by the second method was $3.4 \cdot 10^{11} 1 / \mathrm{km}$. The particulate matter emission determined for the motorway section has reached the same values for both methods and was equal to $5.5 \cdot 10^{11} 1 / \mathrm{km}$. The average particle number road emission in the entire RDE test was higher for the method using all measurement data and reached the value of $9.1 \cdot 10^{11} 1 / \mathrm{km}$, while the emission value obtained by the EMROAD method was $8.4 \cdot 10^{11} 1 / \mathrm{km}$.

The differences in the numerical emission of particles obtained by the two methods for the CI engine are not as large as in the case of particle emissions from the hybrid vehicle. The biggest difference is noticeable in the case of $\mathrm{PN}$ emissions for urban driving. The emission determined by the EMROAD method was $1.4 \cdot 10^{12} 1 / \mathrm{km}$ and was $2 \cdot 10^{11} 1 / \mathrm{km}$ greater than the emission obtained by the second method. The average particle number emission in urban driving was very similar for both analysis methods and reached the value of approx. $5.7 \cdot 10^{12} 1 / \mathrm{km}$. For motorway driving, the average PN emission value was again similar for both methods and amounted to approx. $4.2 \cdot 10^{12}$ $1 / \mathrm{km}$. In the whole RDE test, the diesel vehicle emitted $8.1 \cdot 10^{12} 1 / \mathrm{km}$ according to the EMROAD method and $7.7 \cdot 10^{12} 1 / \mathrm{km}$ for the other method.

The PN emission determined for a vehicle with a gasoline engine in the urban section using the all data method was $1 \cdot 10^{12} 1 / \mathrm{km}$ and was more than $1 / 3$ higher than the emission obtained with the EMROAD method. On the other hand, the road emission of PN in the rural section was greater for the moving averaging windows method at $9.2 \cdot 10^{11} 1 / \mathrm{km}$, while the method of all measurement data obtained the value $8.4 \cdot 10^{11} 1 / \mathrm{km}$. In the case of motorway section, the average PN road emission determined using the 
EMROAD method is more than double that of the second method and amounts to $9 \cdot 10^{11} 1 / \mathrm{km}$. Similarily to the case of $\mathrm{CO}$ emission results, the emission for the whole RDE test obtained using both methods is similar, despite large differences in values for individual drive sections. The average PN emission in the test was $8.2 \cdot 10^{11} 1 / \mathrm{km}$ according to the moving averaging window method and $7.6 \cdot 10^{11} 1 / \mathrm{km}$ for the second method.

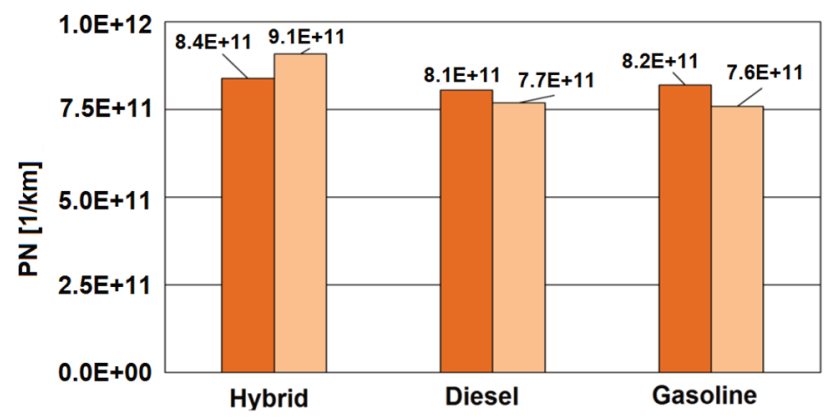

Fig. 18. Particle number emission for each of the vehicles in the whole RDE test (EMROAD and all data)

Although the particle number emission is a problem for gasoline engines mostly limited only to solutions with direct gasoline injection, and the tested vehicle was equipped with an MPI gasoline engine, it was assumed for the test results analysis that the vehicle is subject to the numerical limit of particle emission equal to $6 \cdot 10^{11} 1 / \mathrm{km}$. The adopted limit applies to vehicles with SI DI engines starting from September 2017, replacing the temporary limit of $6 \cdot 10^{12}$ $1 / \mathrm{km}$. The $\mathrm{CF}_{\mathrm{PN}}$ particle number emission factor has not yet been announced, but in the future it is expected to be 1.5 . As part of the analysis of particle emissions, $\mathrm{CF}_{\mathrm{PN}}$ emission conformity factors for each drive section were calculated and compared to the mentioned limit value of 1.5.

The hybrid vehicle exceeded the particle matter emission factor only in the urban drive section. According to the method using all measurement data, the factor was exceeded almost twice - and reached the value 2.91. In the EMROAD method, this factor was 2.37 . For this vehicle driving in the rural and motorway sections, the PN emission factor was less than 1 , meaning that the road emission did not exceed the limit of $6 \cdot 10^{11} 1 / \mathrm{km}$. The $\mathrm{CF}_{\mathrm{PN}}$ value for the whole test drive was equal to 1.5 according to the method using all data and 1.40 according to the EMROAD method, which means that the number of particles the vehicle emitted in the entire test was close to the emission limit value defined for standard RDE tests (Fig. 19).

The $\mathrm{CF}_{\mathrm{PN}}$ values for individual drive sections and for the entire test for a diesel vehicle are very similar to those of the $\mathrm{CF}_{\mathrm{PN}}$ for a hybrid vehicle. The permitted limit value of $1.5 \mathrm{CF}_{\mathrm{PN}}$ is exceeded only in the case of urban driving and reaches a maximum value of 2.36 according to the moving averaging windows method. In the rural and motorway sections, the emission factor value does not exceed 1 , which again means that the average particle number emission in these sections does not exceed the limit specified in the Euro 5 standard. The PN emission factor for the whole RDE test of the diesel vehicle was on average around 1.3 , i.e. the emission exceeded the limit value of the Euro 5 standard, but it did not exceed the allowed PN emission deviation of the emission conformity factor in real driving conditions.

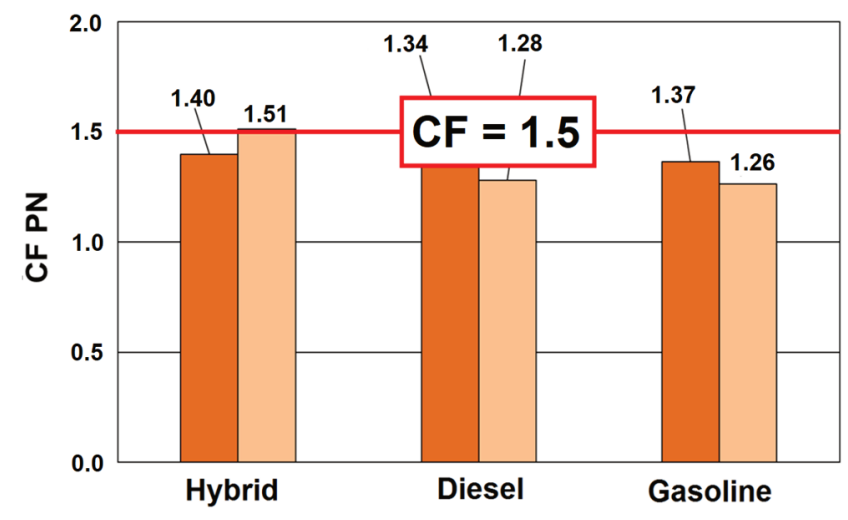

Fig. 19. Particle number emission conformity factor values for each of the vehicles in the whole RDE test (EMROAD and all data)

The test results showed that the diesel vehicle indeed emitted more than three times more nitrogen oxides than the current standard allows, thus exceeding the permissible value of the $\mathrm{CF}_{\mathrm{NOx}}$ emission factor, which confirms the results of many domestic and foreign research centers [11, $16,20]$. Both the tested hybrid vehicle, equipped with an SI engine and a vehicle equipped with only a gasoline engine, exceeded the limit of particle number emission, but their emission did not meet the minimum values set in the form of conformity factors, or exceed them. The hybrid vehicle and the gasoline vehicle were equipped with an indirect, multi-point gasoline injection, and thus the PN emission limit does not apply to these vehicles. The vehicle with the diesel engine, like the other vehicles, also exceeded the PN emission limit, but its emission factor did not reach the maximum permissible value. The average $\mathrm{CO}$ road emission from all vehicles in individual driving sections and in the whole RDE test was small and did not exceed the limits set by the standards. The average $\mathrm{NO}_{\mathrm{x}}$ road emission from the hybrid vehicle and the gasoline vehicle was relatively small, both in individual drive sections and in the entire RDE test and also did not exceed the Euro limits.

\section{Standardization of exhaust emission results - relation to carbon dioxide road emission}

The performed emissivity verification tests of passenger cars with internal combustion engines (Gasoline, Diesel, complying with Euro 3-Euro 6 emission limits) in real driving conditions constituted the first verification of the value and usefulness of the developed tool - a universal onboard exhaust emissions measurement system. Determining the emissivity in road conditions and comparison with the values of road carbon dioxide emissions made it possible to determine the coefficient of Standardization of Exhaust Emission (SEE).

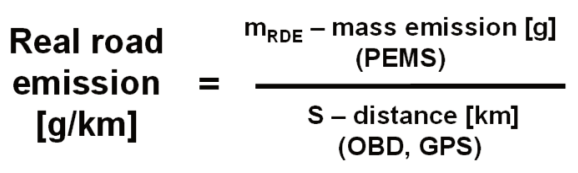




\section{SEE $[\%]=\frac{\text { Real road emission }[\mathrm{g} / \mathrm{km}]}{\mathrm{CO}_{2} \text { real road emission }[\mathrm{g} / \mathrm{km}]}$}

Analysis of the data presented in Fig. 20 and 21 shows that the coefficient values obtained in real operation are smaller the higher the vehicles emission class. For gasoline engines, the SEE index for the emissions of carbon monoxide, hydrocarbons and nitrogen oxides ranges from $0.001 \%$ to $0.5 \%$ (Fig. 20). For CI engines, the SEE index related to the emission of carbon monoxide, hydrocarbons, nitrogen oxides and particulate matter ranges from $0.01 \%$ to $4 \%$ (Fig. 21).

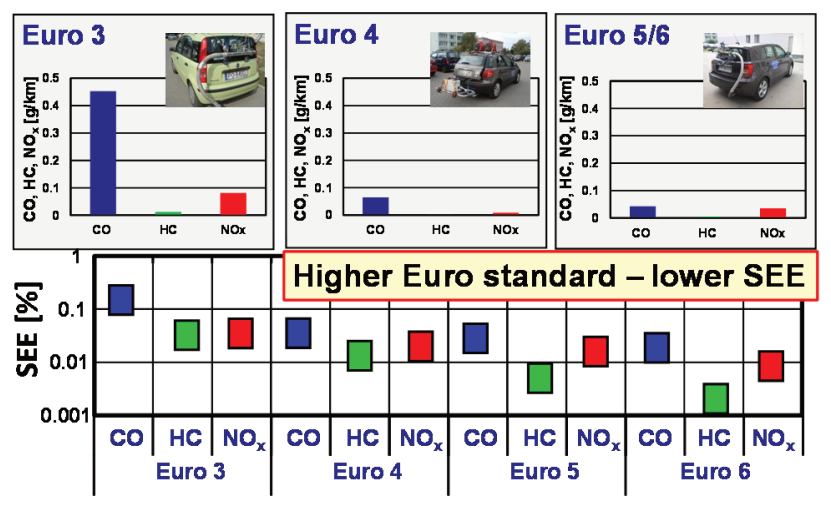

Fig. 20. Gasoline PC - standardization of exhaust emission

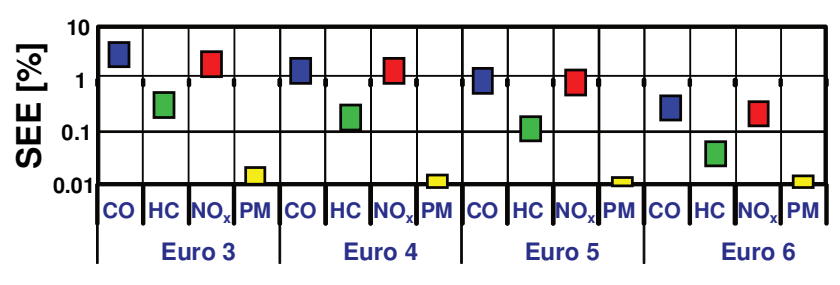

Fig. 21. Diesel PC - standardization of exhaust emission

Comparison of these results indicates that the SEE coefficient for vehicles with Diesel engines reaches values around 10 times greater than for vehicles with Gasoline engines.

\section{Exhaust emission tests for city buses}

Urban public transport plays an important role for cities and their inhabitants in many ways. It ensures a more economic use of natural resources and is less harmful to the environment than individual automotive transport. Public transport is therefore the main pillar of urban mobility for the future. However, this is only possible if urban public transport vehicles are low-emission. A large part of the city public transport is ecological in many ways already. Road transport is responsible for around 54\% of nitrogen oxide emissions and $10 \%$ of particulate emissions. The reduction of these two components of exhaust emissions as well as carbon dioxide (fuel consumption) is currently the key issue in the development of urban bus drives $[7,15,20]$. The Polish market of urban buses numbers around 12,000 and has been quite stable for several years $(50 \%$ of the vehicles used are 10 years or younger). However, it should be men- tioned that there is an increasingly frequent replacement of the old bus fleet with modern (hybrid and electric) solutions, which is related to the EU transport decarbonization plan (Fig. 22). This plan assumes that by 2030, the emission of carbon dioxide in transport will decrease by over $9 \%$ (and by 2050 by more than a half). It should be mentioned that only in 2015 Solaris sold 1,300 low-floor buses with various types of drives (including 946 to foreign markets). Intensive efforts are also made towards the implementation of hybrid and electric buses for mass production (fueled by fuel cells for example) $[14,16]$.

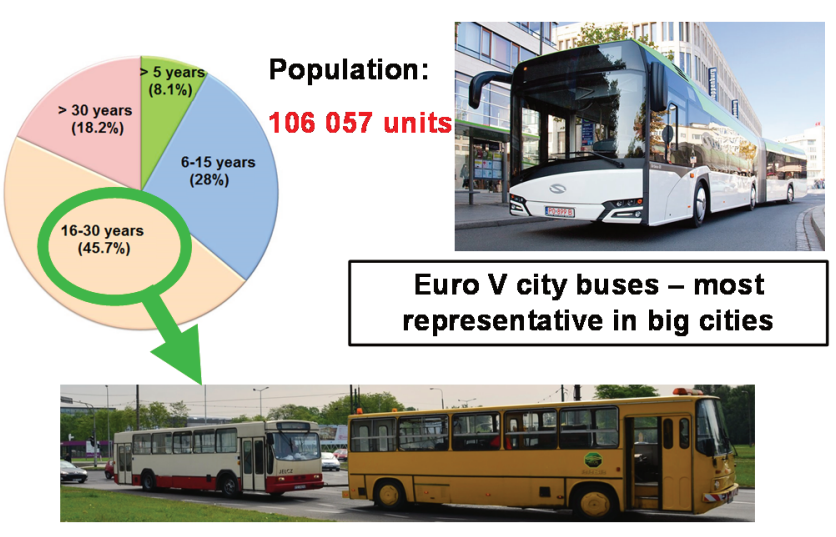

Fig. 22. Buses in Poland (2016)

There exist legal, scientific and technical actions related to reducing the negative impact of these transport modes on the human environment in Poland as well as all around the world. Positive results of activities in this field are noted, including introducing further legal regulations to contribute to the protection of the environment. Such activities are also observed in relation to mass transport means - city buses, and especially to the drive systems used in them. As a result of such activities, more ecological constructions for city bus drives are being developed, as well as their continuous improvement in terms of reduced emissions and fuel economy [17, 22, 27].

The tests used municipal buses with similar functional properties. The first test vehicle was equipped with a conventional drive system with a Diesel engine, the second with a hybrid drive in serial configuration, and the third with an SI engine powered with compressed natural gas (Table 2). To prepare vehicles for testing, a replacement load was used to reflect the load generated by passengers during daily use.

The tests of specific exhaust emission and drive system operating parameters were performed in the SORT drive tests (Fig. 23) and in real operating conditions (Fig. 24). Measurements in standardized tests covered the test drive cycles SORT 1, SORT 2, as well as SORT 3, where three tests were performed. The requirements listed by the methodology developed by UITP were met. The selection of test routes No. 1, 2 and 3 was made with the assumption that they would be as close as possible to the SORT tests in terms of the nature of the route (urban conditions of different traffic intensity and suburban conditions) as well as the vehicle speeds obtained. In these test cycles, three tests were performed for each of the test vehicles. Exhaust emis- 
sion measurements on the city bus line were made during the rush hour, when the buses operate the stops at the highest frequencies. The results presented in the article are only referenced to the SORT 2 test, as it was found that this test reflects the conditions of city buses operation the most of the three tests performed.

Tab. 2. Technical characteristics of vehicles used for tests

\begin{tabular}{|c|c|c|c|}
\hline \multirow[b]{2}{*}{ Parameter } & DIESEL & HYBRID & CNG \\
\hline & & & \\
\hline Typelfuel & \multicolumn{2}{|c|}{ 4-stroke, R6, DIESEL } & $\begin{array}{c}\text { 4-stroke } \\
\text { R6 SI/CNG }\end{array}$ \\
\hline Displacement [L] & 9.2 & ! (6.7)(Serial) & 8.9 \\
\hline $\begin{array}{l}\text { Maximum power } \\
{[\mathrm{kW}] /[\mathrm{rpm}]}\end{array}$ & $265 / 1900$ & $\begin{array}{c}209 / 2300 \\
+(\text { SE } 240 \mathrm{~kW})\end{array}$ & $239 / 2000$ \\
\hline $\begin{array}{l}\text { Maximum torque } \\
{[\mathrm{N} \cdot \mathrm{m}] /[\mathrm{rpm}]}\end{array}$ & $1450 / 1100-1700$ & $1008 / 1200-1800$ & $1356 / 1300-1400$ \\
\hline Exhaust aftertreatment & \multicolumn{2}{|c|}{ SCR/DPF } & TWC \\
\hline Emission standard & \multicolumn{3}{|c|}{ Euro V-EEV } \\
\hline
\end{tabular}

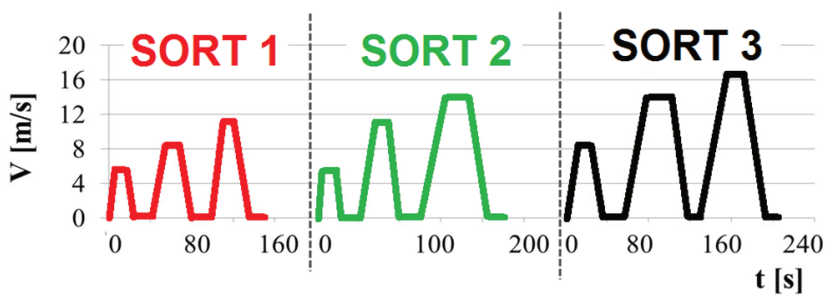

Fig. 23. Standardized on-road test: 1 - urban + heavy traffic, 2 - urban, 3 - suburban

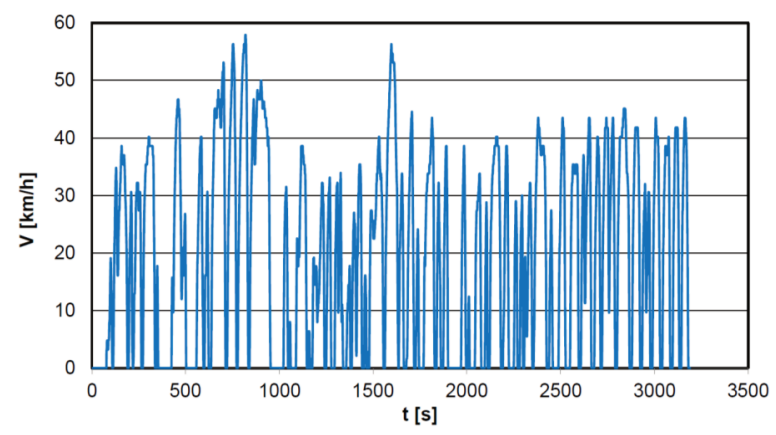

Fig. 24. Vehicle speed characteristic on the city buses test route

The analysis of the internal combustion engines dynamic operating conditions in real operation can be simplified to the analysis of a given parameter in the vehicle speedacceleration coordinates. This approach is similar to the analysis of the engines static characteristics in the coordinates of the engine-load and speed. If the entire vehicle with the drive system is treated as a "closed object" (a socalled black box), then making such an assumption allows analysis of selected exhaust emission components regardless of internal changes taking place in the considered system. This assumption does not exclude the simultaneous collection of the drive system operating data (including the engine speed and load obtained from the on-board diagnos- tic system). The description of any parameter, e.g. the emission intensity of a given exhaust component, in coordinates, e.g. vehicle speed-acceleration was made using twodimensional probability density histograms, which constitute a record of the duration of individual engine load being in a given interval or their share of the total duration. Although such characteristics do not take into account the dynamic properties of the engine, defined on the basis of engine control-torque relationship, the published optimization results based on their use indicate that such simplification is acceptable.

In order to compare the share of bus operating time in the selected speed and acceleration intervals, differences were determined between these values as obtained in tests on the route No. 2 and in the SORT 2 drive test (Fig. 25). Analysis of the graphs indicates that for the conventional vehicle the average value obtained was $1.5 \%$. For the intervals described by the parameters $\left(0 \mathrm{~m} / \mathrm{s} ; 0 \mathrm{~m} / \mathrm{s}^{2}\right)$ and $(6-10$ $\left.\mathrm{m} / \mathrm{s} ; 0-0.8 \mathrm{~m} / \mathrm{s}^{2}\right)$, as well as $\left(12-14 \mathrm{~m} / \mathrm{s} ;-1.6-0.8 \mathrm{~m} / \mathrm{s}^{2}\right)$ the largest differences of more than $5 \%$ were found.

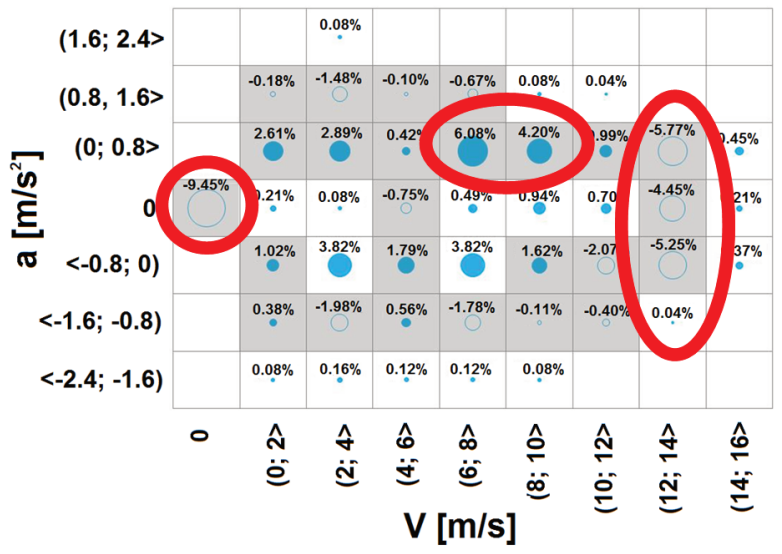

Fig. 25. Difference in the operating time density of test vehicles between measurements on the test route and in the SORT 2 test, shown in the speed and acceleration intervals for the vehicle with a CI engine

The conventional bus drive system (Fig. 26) in the city road tests spent $9 \%$ less time in the interval $(600 \mathrm{rpm}, 800$ $\mathrm{rpm})$ and $(0 \mathrm{~N} \cdot \mathrm{m} ; 200 \mathrm{~N} \cdot \mathrm{m})$ as well as $3.8-5.6 \%$ in the $(1400 \mathrm{~N} \cdot \mathrm{m} ; 1600 \mathrm{~N} \cdot \mathrm{m})$ load interval.

Analysis of the measured exhaust components emission intensity, presented in the engine speed and load intervals, allows to find the impact of the combustion engine operation parameters on the exhaust content of individual harmful components. For a conventional bus the highest intensity of carbon monoxide emission occurred in the full range of recorded speed values with a load greater than $1200 \mathrm{~N} \cdot \mathrm{m}$ - the average value of this parameter is $196 \mathrm{mg} / \mathrm{s}$ (Fig. 27). Such a distribution of data is primarily the result of the engine characteristics, where at high load the injected fuel dose did not mix properly and incomplete combustion occurred. In a vehicle equipped with a hybrid drive, the emission intensity of the carbon monoxide depends mainly on the torque generated by the engine. For the third test vehicle, the content of the analyzed compound was mainly influenced by the rotational speed of the crankshaft, and to a lesser extent the engine load. For the interval of the 


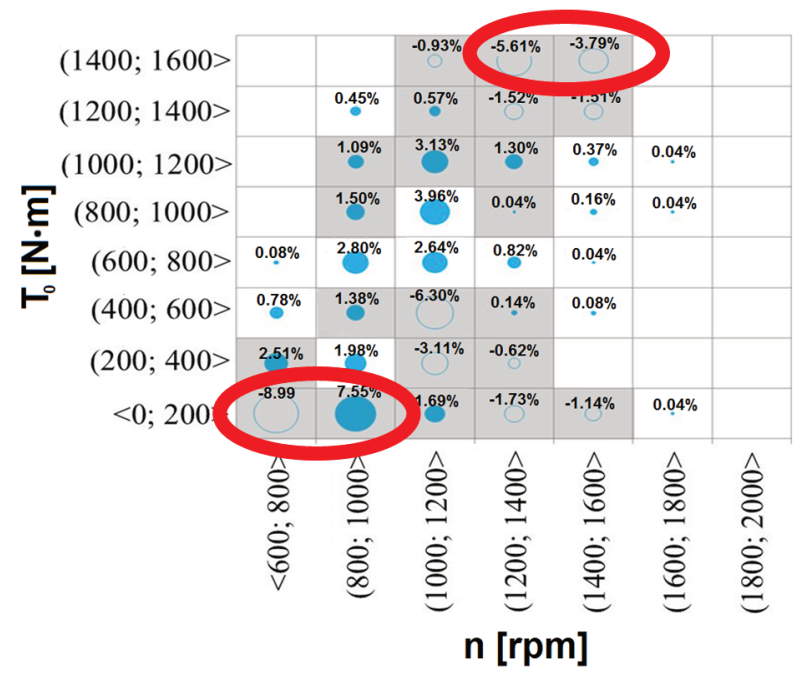

Fig. 26. Difference in the operating time density of test vehicles between measurements on the test route and in the SORT 2 test, shown in the engine speed and load intervals

a)

b)
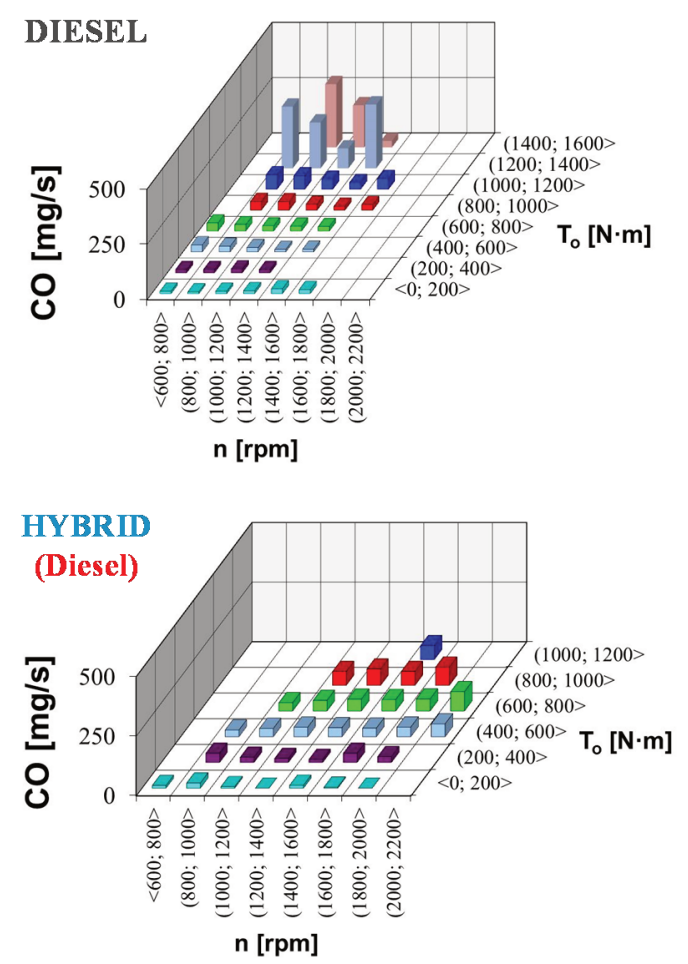

c)

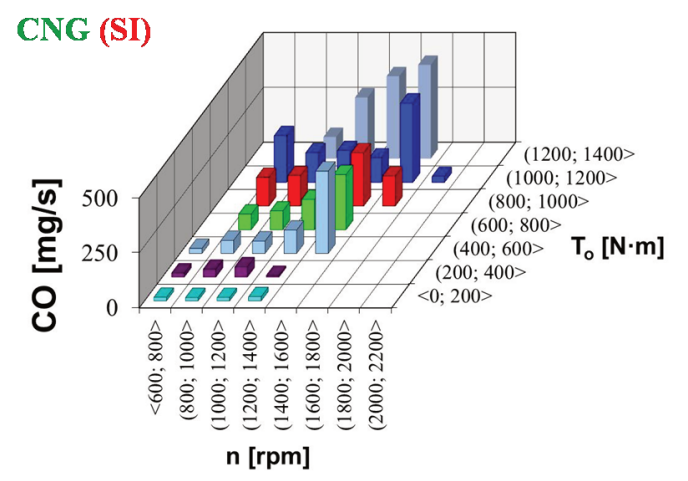

Fig. 27. Carbon monoxide emission intensity in road tests: a) bus with a diesel engine, b) hybrid bus, c) bus powered by natural gas highest torque value, an average value of $295 \mathrm{mg} / \mathrm{s}$ carbon monoxide emission was measured.

A strong dependence of the nitrogen oxides emission intensity on the engine load can be seen for the conventional bus (Fig. 28). The highest values of the exhaust component were observed in the interval where torque was greater than $1200 \mathrm{~N} \cdot \mathrm{m}$, where the average emission intensity measured reached $169 \mathrm{mg} / \mathrm{s}$. The hybrid vehicle also shows a significant importance of the engine rotational speed on the emission of this component. In the engine speed interval of up to approximately 1,400 rpm, the $\mathrm{NO}_{\mathrm{x}}$ emission intensity values did not exceed $140 \mathrm{mg} / \mathrm{s}$, which was the result of the electric system being used in the vehicle. Electric energy accumulated in batteries and supercapacitors effectively supported the operation of the internal combustion engine. The average nitrogen oxide emission intensity in the speed interval above $1600 \mathrm{rpm}$, for loads greater than $400 \mathrm{~N} \cdot \mathrm{m}$, was $267 \mathrm{mg} / \mathrm{s}$. Such high values were obtained mostly due to the parameters of the engine used in this vehicle, which had the lowest rated power among the tested vehicles. In a hybrid bus, due to the very high efficiency of the catalytic

a)

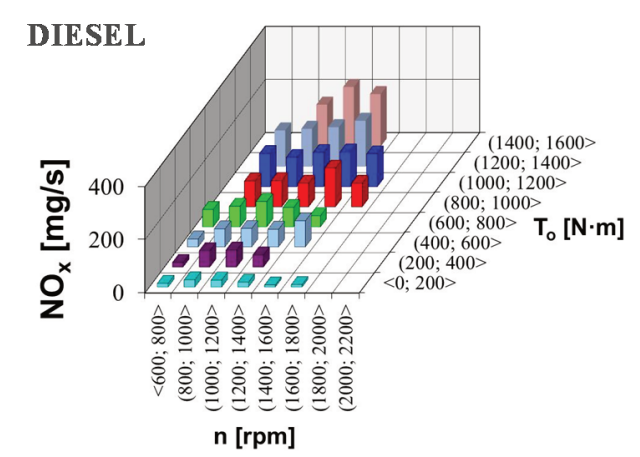

b)

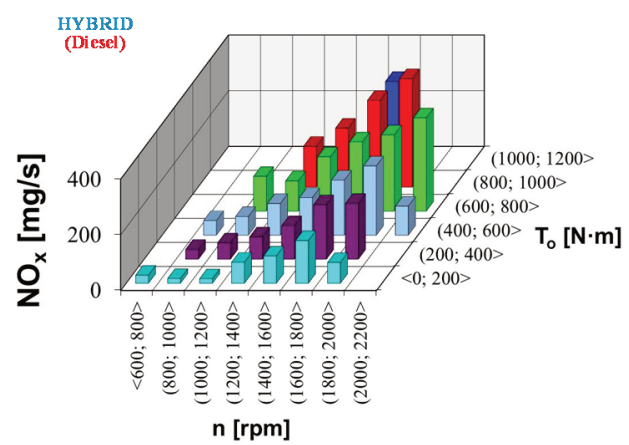

c)

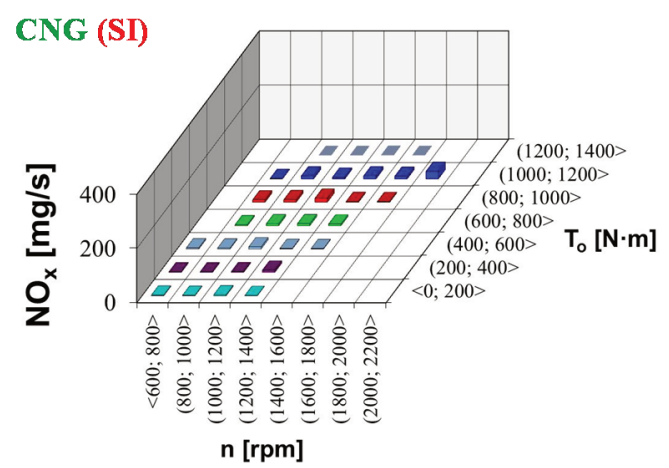

Fig. 28. Nitrogen oxides emission intensity in road tests: a) bus with a diesel engine, b) hybrid bus, c) bus powered by natural gas 
converter used in the reduction of nitrogen oxides, the maximum emission intensity of the analyzed exhaust component did not exceed $28 \mathrm{mg} / \mathrm{s}$.

Based on the obtained specific exhaust emission results it is possible to refer their value to the emission limits that these test vehicles meet (Euro V-EEV). In order to do this, the emission conformity factor $\mathrm{CF}$ has to be determined. Since the CNG alternative fuel bus achieved CO emission values that were significant among the tested exhaust emissions in relation to the legislative guidelines, whereas for the vehicles with SI engines a similar situation occurred for the $\mathrm{NO}_{\mathrm{x}}$ emission values, further considerations were focused on these two exhaust compounds.

The specific CO emission conformity factors (Fig. 29) show that the vehicle with a conventional drive obtained values greater than 1 in both the SORT 1 test and on test route No. 1, which means that the legal emission limits were exceeded. For the hybrid bus the calculated $\mathrm{CF}_{\mathrm{CO}}$ factors were in the range of $0.14-0.85$ for all measurement drive cycles. The exhaust emission values obtained for the third vehicle were greater than 1 in four cases (maximum 1.68 for the SORT 1 test).

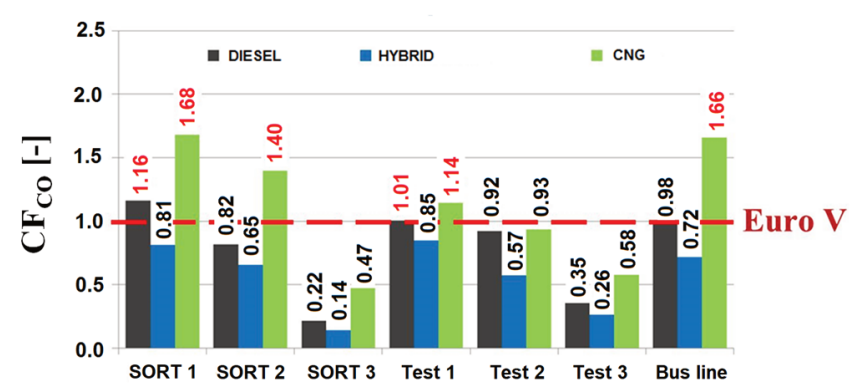

Fig. 29. Carbon monoxide emission conformity factor $\mathrm{CF}_{\mathrm{CO}}$ obtained from measurements in real operating conditions and the Euro V-EEV emission limits

For the $\mathrm{CF}_{\mathrm{NOx}}$ factors it can be stated, that the smallest values were found for a bus powered by compressed natural gas and they were within the range of 0.16-0.32 (Fig. 30). Tests of the conventional vehicle powered with diesel oil have shown, that the exhaust emission limits were exceeded in the standardized SORT 1 and SORT 2 drive tests, on test route No. 1, as well as on the municipal bus line. The highest obtained values of the $\mathrm{CF}_{\mathrm{NOx}}$ factor (from 1.76 to 3.36 ) were observed for a hybrid bus in all analyzed test drive cycles. A major influence on this distribution of results were the exhaust gas aftertreatment systems placed in the exhaust systems of these vehicles. The first and second tested buses used the SCR system that did not reduce $\mathrm{NO}_{\mathrm{x}}$ continuously, but the degree of conversion depended on multiple factors, including exhaust mass flow and exhaust temperature.

The specific exhaust emission values are determined in type approval tests using the net engine performance parameters measured at the end of the crankshaft or its equivalent. In real operating conditions, the internal engine resistance is expressed as a percentage - one specific value for the entire engine speed range. However, it should be noted that this is a certain simplification affecting the final results of the research.

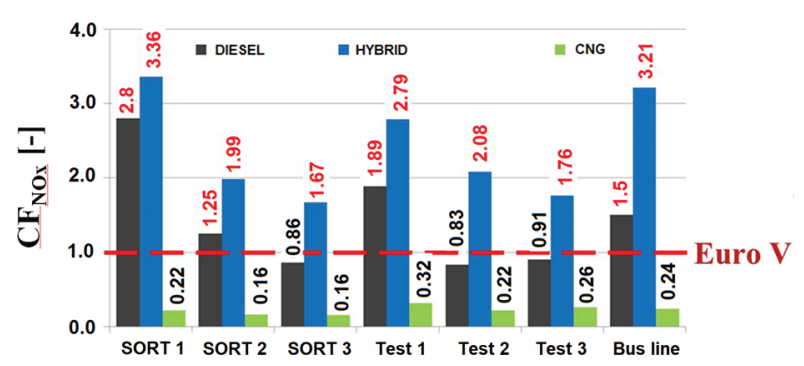

Fig. 30. Nitrogen oxides emission conformity factor $\mathrm{CF}_{\mathrm{NOx}}$ obtained from measurements in real operating conditions and the Euro V-EEV emission limits

\section{Conclusions}

Having a developed concept and research methodology for measuring exhaust emissions in real operating conditions for all means of transport equipped with combustion engines, using on-board diagnostics systems and measuring emissions while driving, is a modern achievement. In addition to emission measurements from motor vehicles (as well as off-road vehicles), exhaust emission measurements are also coordinated for trucks, buses, including hybrid vehicles, construction and agricultural machines (non-road), rail vehicles, ships, boats and aircraft with piston and jet engines. These activities assess the on-board emissions using measuring devices referred to as PEMS (Portable Emission Measurement System). These include devices for measuring gaseous exhaust emissions $\left(\mathrm{CO}, \mathrm{CO}_{2}, \mathrm{HC}, \mathrm{NO}_{\mathrm{x}}\right)$ as well as particulate matter (including mass, number and size distribution) $[23,37]$, and at the same time using data acquisition systems - collecting registered engine and vehicle operating parameters using on-board diagnostic systems or black boxes. The latter were introduced to vehicles through the development and implementation tests of onboard recording devices in motor vehicles.

The current level of measurement technology related to exhaust emission testing allows testing emission from means of transport in real operating conditions. The biggest disadvantage of such tests is the high cost of the measuring equipment and its adaptation to the vehicle exhaust systems and use in vehicles. Such measurements are currently carried out in all countries where environmental protection is a priority in order to compare the measuring capabilities of various measuring devices for various vehicles. As a result, the move towards legally acknowledging the measurement of vehicle exhaust emissions in real operating conditions is perceived as the final test to verify the vehicle as a whole in terms of its exhaust emissions. This type of research allows to determine the level of emission values of individual exhaust components in real driving conditions. In addition, they enable assessing the operational characteristics of the tested means of transport in terms of the operating time density for the engine load intervals and determining the engine operating conditions together with their share in the total operating time during the test. Such information may be compared to the results obtained using stationary engine and vehicle test procedures, which in the future may further the optimization of the engine operating points that are used in various modes of transport.

The research was funded by project co-financed by the European Regional Development Fund in the Regional Program - Wielkopolskie 2020 (contract No. RPWP.01.02.00-30-0069/16) 


\section{Nomenclature}

a acceleration

$\mathrm{a}_{\text {pos }} \quad$ positive acceleration

$\mathrm{b}$ road exhaust emissions value

$\mathrm{CF}$ conformity factor

CI compression ignition

CNG compressed natural gas

DI direct injection

EEV enhanced environmental friendly vehicle

EMROAD methods used to analyze on-road emissions data collected with portable emissions measurement systems

EOBD European on-board diagnostic

EU European Union

Euro standard emissions

GPF gasoline particle filter

GPS global positioning system

HEV hybrid electric vehicle

ICE internal combustion engine

GPF gasoline particle filter
MPI multi point injection

NEDC new European driving cycle

OBD on-board diagnostics

PEMS portable emission measurement system

PHEV plug-in hybrid electric vehicle

PMP Particle Measurement Programme

PM particle mass

PN particle number

RDE real driving emissions

RPA relative positive acceleration

S distance

SI spark ignition

SORT standardised on-road test cycles

SSE standardization of exhaust emission

u share

UITP international association of public transport

WLTC worldwide harmonized light vehicles test cycle

V velocity

\section{Bibliography}

[1] ANDERSSON, J. Particle number (PN) measurement experiences from 2016 AECC GDI GPF project. AECC Technical Seminar on Real-Driving Emissions of Particles (RDE PN), Diamant Conference Centre, Brussels 2016.

[2] ANDRYCH-ZALEWSKA, M. Wpływ katalizatora wewnętrznego na emisję spalin w stanach pracy silnika o zapłonie samoczynnym odpowiadających jego użytkowaniu trakcyjnemu. Rozprawa doktorska. Poznań 2018.

[3] BIELACZYC, P., MERKISZ, J., PIELECHA, J., WOODBURN, J. A comparison of gaseous emissions from a hybrid vehicle and a non-hybrid vehicle under real driving conditions. SAE Technical Paper 2018-01-1272, 2018.

[4] BIELACZYC, P., WOODBURN, J., KLIMKIEWICZ, D. et al. An examination of the effect of ethanol-gasoline blends physicochemical properties on emissions from a light duty spark ignition engine. Fuel Processing Technology. 2013, 107, 50-63.

[5] BOUGHER, T., KHALEK, I.A., TREVITZ, S., AKARD, M. Verification of a gaseous portable emissions measurement system with a laboratory system using the Code of Federal Regulations Part 1065. SAE Technical Paper 201001-1069, 2010.

[6] CHŁOPEK, Z. et al. Assessment of the impact of dynamic states of an internal combustion engine on its operational properties. Eksploatacja i Niezawodnosc-Maintenance and Reliability. 2015, 17(1), 35-41.

[7] CHŁOPEK, Z. et al. Modelling of motor vehicle operation for the evaluation of pollutant emission and fuel consumption. Combustion Engines. 2017, 171(4), 156-163.

[8] Commission Regulation (EC) 692/2008 of 18 July 2008 implementing and amending Regulation (EC) No 715/2007 of the European Parliament and of the Council on typeapproval of motor vehicles with respect to emissions from light passenger and commercial vehicles (Euro 5 and Euro 6 ) and on access to vehicle repair and maintenance information, European Commission (EC), Official J. European Union, L 199, 2008.

[9] Commission Regulation (EC) 715/2007 of the European Parliament and of the Council of 20 June 2007 on type approval of motor vehicles with respect to emissions from light passenger and commercial vehicles (Euro 5 and Euro 6 ) and on access to vehicle repair and maintenance information, European Commission (EC), Official J. European Union, L 171, 2007.

[10] Commission Regulation (EU) 2016/427 of 10 March 2016 amending Regulation (EC) No 692/2008 as regards emissions from light passenger and commercial vehicles (Euro 6), Verifying Real Driving Emissions, Official J. European Union, L 82, 2016.

[11] Commission Regulation (EU) 2016/646 of 20 April 2016 amending Regulation (EC) No 692/2008 as regards emissions from light passenger and commercial vehicles (Euro 6), Verifying Real Driving Emissions, Official J. European Union, L 109, 2016.

[12] Energy Technology Perspectives. 2017.

[13] FRANCO, V., KOUSOULIDOU, M., MUNTEAN, M. et al. Road vehicle emission factors development: a review. Atmospheric Environment. 2013, 70, 84-97.

[14] FUĆ, P., RYMANIAK, Ł., ZIÓŁKOWSKI, A. The correlation of distribution of PM number emitted under actual conditions of operation by PC and HDV Vehicles. WIT Transactions on Ecology and the Environment. 2013, 174, 207219.

[15] GIS, W., MERKISZ-GURANOWSKA, A., PIELECHA, J., GIS, M. Operation of urban buses powered biomethane. E: European Science Society of Powertrain and Transport Publication, Warsaw 2015. Journal of KONES Powertrain and Transport. 2015, 22(3), 2015.

[16] GIS, W., PIELECHA, J., GIS, M. Possibilities for development of electromobility and methanisation of road transport in Poland. FISITA 2016 World Automotive Congress, Paper no. F2016-ESYC-005, Busan 26-30.09.2016.

[17] HENRICHS, T. Clean Air Programme for Europe - update. AECC Technical Seminar on Real-Driving Emissions of Particles (RDE PN), Diamant Conference Centre, Brussels 2016.

[18] JEHLIK, H. Challenge X 2008 - hybrid powered vehicle on-road emissions findings and optimization techniques: a 4 year summary. Sensors 5th Annual SUN (SEMTECH User Network) Conference, 25-26.09.2008. 
[19] MERKISZ, J., BAJERLEIN, M., RYMANIAK, Ł., SIEDLECKI, M. Development of road test to evaluate the fuel consumption in the urban cycle for city buses equipped with hybrid powertrain. Combustion Engines. 2015, 3(162), 587592.

[20] MERKISZ, J., FUĆ, P., LIJEWSKI, P. et al. The research of exhaust emissions and fuel consumption from HHD engines under actual traffic conditions. Combustion Engines. 2014, 158(3), 56-63.

[21] MERKISZ, J., LIJEWSKI, P., FUĆ, P., PIELECHA, J. Exhaust emission tests from agricultural machinery under real operating conditions. SAE Technical Paper Series 201001-1949, 2010.

[22] MERKISZ, J. LIJEWSKI, P., PIELECHA, J. PEMS-based investigations into exhaust emissions from non-road and rail vehicles. Combustion Engines. 2016, 166(3), 46-53.

[23] MERKISZ, J., PIELECHA, J. Nanoparticle emissions from combustion engines. Springer Tracts on Transportation and Traffic. 2015, 8, 139.

[24] MERKISZ, J., PIELECHA, J. Selected remarks about RDE test. Combustion Engines. 2016, 166(3), 54-61.

[25] MERKISZ, J., PIELECHA, I., PIELECHA, J. Gaseous and $\mathrm{PM}$ emission from combat vehicle engines during start and warm-up. SAE Technical Paper 2010-01-2283, 2010.

[26] MERKISZ, J., PIELECHA, J., RADZIMIRSKI, S. New trends in emission control in the European Union. Springer Tracts on Transportation and Traffic, 2014, 4. 170.

[27] NOWAK, M., PIELECHA, J. Comparison of exhaust emission on the basis of Real Driving Emissions measurements and simulations. MATEC Web of Conferences. 2017, 118, 00026.

[28] OCHS, T., SCHITTENHELM, H., GENSSLE, A., KAMP, B. Particulate matter sensor for on board diagnostics (OBD) of diesel particulate filters (DPF). SAE Technical Paper 2010-01-0307, 2010.

[29] PIELECHA, J. Identyfikacja parametrów cząstek stałych z silników spalinowych. Rozprawa habilitacyjna, Rozprawy $\mathrm{nr}$ 467. Wydawnictwo Politechniki Poznańskiej. Poznań 2012.

[30] PIELECHA, J., MAGDZIAK, A., BRZEZINSKI, L. Nitrogen oxides emission evaluation for Euro 6 category vehicles equipped with combustion engines of different displacement volume. International Conference on the Sustainable Energy and Environment Development, SEED 2017, E3S Web of Conferences. 2017, 10, 00073.

[31] PIELECHA, J., MERKISZ, J., MARKOWSKI, J., JASIŃSKI, R. Analysis of passenger car emission factors in RDE tests. International Conference on the Sustainable En- ergy and Environment Development. E3S Web of Conferences. 2016, 10, 00073.

[32] PIELECHA, J., MERKISZ, J., MARKOWSKI, J., JASIŃSKI, R. Evaluation of exhaust emissions of vehicles with emission Euro 6 Class according to RDE tests proposed by the European Union. 20th ETH Conference on Combustion Generated Nanoparticles, Zurich, 13-16.06.2016.

[32] SCHWENGER, C., WAGNER, U., SPICHER, U. Investigation of the inflow behavior of a diesel particulate filter using laser-optical measurement techniques during soot loading and filter regeneration with the aim of improving these processes. THIESEL Conference on Thermoand Fluid Dynamic Processes in Diesel Engines, Valencia 2010.

[34] SEGER, J.P. Vehicle integration for US EPA 2010 emissions and lowest cost of ownership. SAE Technical Paper 2010-01-1956, 2010.

[35] STEININGER, N. Automotive particulate emissions in European legislation: state of the art and developments to come. 13th ETH Conference on Combustion Generated Particles, Zurich 2009.

[36] STÜTZ, W. Diesel engines for the future of mobility. New technology developments at BMW. Engine 2020: Spark versus compression ignition in a new environment. International AVL Conference „Engine \& Environment”, Graz 2014.

[37] STELMASIAK, Z., LARISCH, J., PIELECHA, J., PIETRAS, D. Particulate matter emission from dual fuel diesel engine fuelled with natural gas. Polish Maritime Research. 2017, 2(94), 96-104.

[38] SZYMLET, N., RYMANIAK, Ł., LIJEWSKI, P. et al. Research and analysis of harmful road emission from a twowheel vehicle engine in laboratory conditions. Combustion Engines. 2018, 173(2), 41-46.

[39] WEI, Q., ROONEY, R. The on-board PM mass calibration for the real-time PM mass measurement. SAE Technical Paper 2010-01-1283, 2010.

[40] WOODBURN, J., BIELACZYC, P., MERKISZ, J., PIELECHA, J. Gaseous emissions from a hybrid vehicle and a non-hybrid vehicle measured under real driving conditions via PEMS. FISITA 2018 World Automotive Congress, F2018-PTE-266, Chennai, India 2-5.10.2018.

[41] Worldwide emission standards. Passenger cars and light duty vehicles. Delphi. Innovation for the real world. 2017/2018.
Prof. Jerzy Merkisz, DSc., DEng. - Faculty of Transport Engineering, Poznan University of Technology.

e-mail: Jerzy.Merkisz@put.poznan.pl

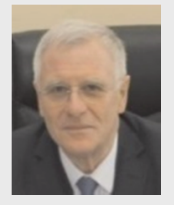

Prof. Jacek Pielecha, DSc., DEng. - Faculty of Transport Engineering, Poznan University of Technology.

e-mail: Jacek.Pielecha@put.poznan.pl 